\title{
O PAPEL ATUAL DAS ESCOLAS DE DIREITO ANTE AS MUDANÇAS SOCIAIS E AS EXIGÊNCIAS JURÍDICAS DO MUNDO PÓS-MODERNO
}

\author{
THE CURRENT ROLE OF THE LAW SCHOOLS IN FRONT OF SOCIAL CHANGES AND
}

THE LEGAL REQUIREMENTS OF THE POSTMODERN WORLD

\author{
Marcus Geandré Nakano Ramiro* \\ Suelyn Moraes Giordani**
}

\begin{abstract}
RESUMO: Este artigo apresenta uma breve análise sobre a educação jurídica no Brasil, destacando as deficiências de suas Escolas de Direito ante as grandes mudanças sociais e as exigências jurídicas atuais. Demonstra ainda a necessidade do desenvolvimento conjunto dos enfoques zetético e dogmático do fenômeno jurídico como caminho para a compreensão do bem comum e consequente colaboração na consolidação do Estado Democrático de Direito.
\end{abstract}

PALAVRAS-CHAVE: Educação Jurídica. Cursos de Direito. Exigências Jurídicas Atuais. Enfoque Zetético.
ABSTRACT: This article presents a brief analysis on legal education in Brazil, highlighting the deficiencies of its Law Schools in the face of major social changes and current legal requirements. It also demonstrates the need to jointly develop the zetetic and dogmatic approaches to the juridical phenomenon as a way to understand the common good and consequent collaboration in the consolidation of the Democratic Rule of Law.

KEYWORDS: Legal Education. Law Courses. Current Legal Requirements. Zetetic Aproach.

SUMÁRIO: Introdução. 1 As Deficiências Atuais das Escolas de Direito Brasileiras. 2 As Mudanças Sociais e as Exigências Jurídicas Atuais. 3 O Enfoque Zetético e Dogmático do Fenômeno Jurídico. 4 A Busca pelo Bem Comum como um dos Pressupostos à Consolidação do Estado Democrático de Direito. Considerações Finais. Referências.

\section{INTRODUÇÃOO}

O mundo contemporâneo, na complexidade de suas relações humanas e rápidas transformaç̃es, tem reduzido as várias discussões em torno do fenômeno social, a um mero tecnicismo jurídico, desvinculado - muitas vezes - da necessária construção e desenvolvimento de um pensamento crítico e reflexivo, essencial para a consecução de seus objetivos primários.

Neste prisma, os profissionais do Direito, sobretudo os advogados, que nos termos da Constituição Federal de 1988 são classificados como "indispensáveis à administração da justiça", acabam se mostrando incapazes de transformar essa realidade e colaborar para uma melhora nas relações sociais e consequente consolidação da democracia.

\footnotetext{
* Doutor e Mestre em Filosofia do Direito e do Estado pela Pontifícia Universidade Católica de São Paulo (PUCSP). Professor e Coordenador do Curso de Direito da Pontifícia Universidade Católica do Paraná (PUC-PR), campus Maringá. Conselheiro e Presidente da Comissão de Educação Jurídica da Subseção Maringá da Ordem dos Advogados do Brasil (OAB/PR).

${ }^{* * *}$ Bacharel em Direito pela Pontifícia Universidade Católica do Paraná (PUC-PR).
} 


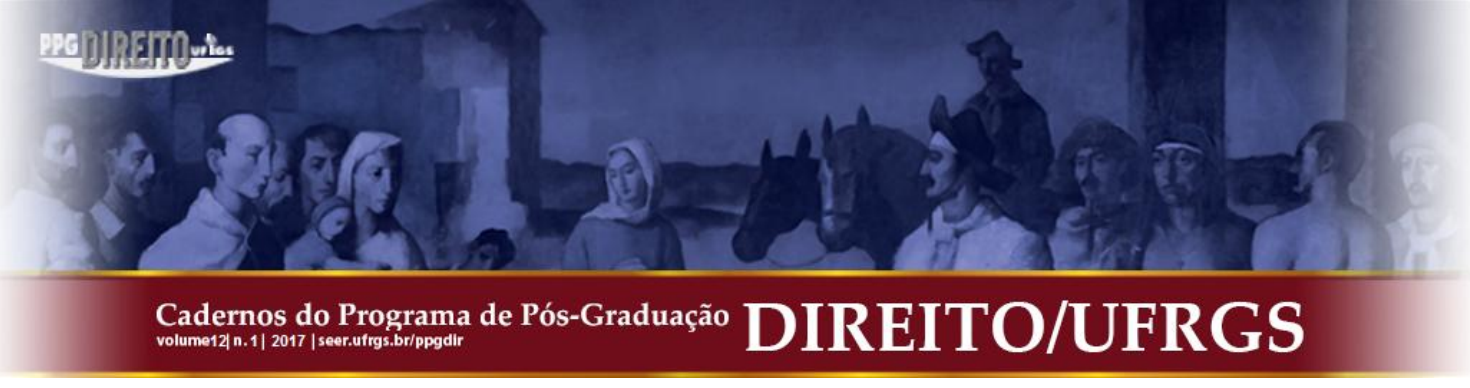

Dentro dos motivos que poderiam justificar tal postura, percebe-se que a forte carga dogmática da ordem jurídica, que implica num sistema unitário e hierárquico de normas, infelizmente possui a preferência quando se trata de exames e concursos para as carreiras ligadas ao mundo do Direito, em detrimento das discussões sobre o verdadeiro foco do fenômeno social - o ser humano.

Dentro dessa perspectiva, a educação jurídica contemporânea vivencia as mais variadas adversidades, relacionadas, por exemplo, à qualidade do ensino, ao aumento exagerado do número de instituições que ofertam cursos jurídicos, somados a um estudo que se mostra predominantemente técnico e que se preocupa, na maioria das vezes, apenas em preparar o estudante para atuar de acordo com as necessidades imediatas do mercado de trabalho, esquecendo-se da dialética essencial entre a academia e a sociedade, fundamental para uma melhor compreensão das demandas sociais.

Diante deste cenário desfavorável e considerando as relações dialéticas descritas acima, percebe-se a necessidade de que o estudo jurídico se dê sob dimensões mais amplas, correlacionando-o com as diversas áreas do saber, de forma a dar condições ao estudante de identificar as causas, as raízes das demandas à sua frente e não apenas saber realizar a subsunção primária que adeque o fato à norma ou se emudecer diante de novas leis que não reflitam a realidade ou façam a diferença na vida dos indivíduos.

Assim, propõe-se uma breve reflexão sobre as deficiências atuais da educação jurídica, com a intenção de demonstrar a importância de se ter cursos de Direito que desenvolvam de forma concomitante o enfoque zetético e dogmático em suas matrizes curriculares, para que, o estudante, tendo acesso ao acervo da humanidade, consiga posteriormente, se sobrepor às problemáticas enfrentadas pela profissão e ajudar efetivamente na construção de uma sociedade pugne pela igualdade e justiça, conforme almejado pela Constituição Federal.

\section{AS DEFICIÊNCIAS ATUAIS DAS ESCOLAS DE DIREITO BRASILEIRAS}

Diante da história cultural, política e econômica do Brasil é fácil constatar que as dificuldades vividas pelo ensino jurídico no país advêm de longa data, quando desde a colonização (ou desde a ocupação) realizada pelos europeus, o ensino como um todo, foi voltado tão somente aos interesses da metrópole. 


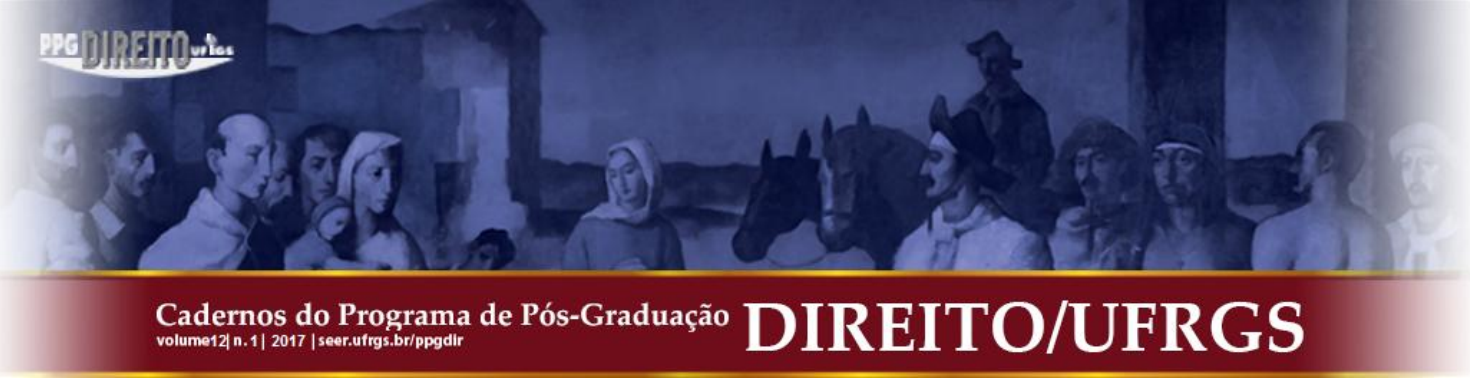

Já nos primeiros momentos da vinda dos europeus para o Brasil, o conhecimento não era algo prioritário e o povo era privado das descobertas científicas que estavam acontecendo em outros países. Ademais, com a Reforma Pombalina, que em Portugal fora realizada com o objetivo de uma reconstrução cultural, o Brasil ficou diante de uma supressão do sistema educacional vigente, não havendo nenhuma reforma cultural, tampouco educacional à época. A parcela mais pobre da população, composta por colonos, escravos africanos e índios, acabou por ficar à deriva, entregues à própria sorte. ${ }^{1}$

Como colônia portuguesa, a preocupação dos governantes da época se limitava à defesa do território e à exploração das terras e dos recursos naturais, o que fez com que os cursos universitários fossem criados de forma tardia no país. Além disso, importante salientar que esta conjuntura foi também influenciada pelo fato de que os doutores das diversas áreas do conhecimento, vindos das universidades europeias, se mostravam suficientes para suprir as demandas brasileiras. $^{2}$

No entanto, após a vinda da família real para o Brasil e diante da necessidade de adequar o país à realidade da corte portuguesa, o governo foi compelido a criar cursos superiores na antiga colônia. Ocorre, entretanto, que a qualidade educacional desses novos cursos se mostrava extremamente baixa se comparada às universidades já existentes. Sob este aspecto Bove afirma que:

[...] foi compelido que fossem criados cursos superiores com pouco critério educacional para atender os anseios imediatos dos filhos da aristocracia colonial dominante. Com isso, o sistema de ensino superior sofreu, já de início, de forma significante, a interferência marcante dessas faculdades, pouco universitárias mas, na essência, com notada coloração política governante da época. ${ }^{3}$

A criação de cursos jurídicos, desta forma, ao invés de propiciar a formação de cidadãos preparados para a solução de conflitos, prestou-se apenas à ocupação de cargos públicos dentro da estrutura estatal, característica que, há de se convir, permanece até os dias de hoje. Wolkmer afirma que os poucos bacharéis que se destacavam como advogados,

\footnotetext{
${ }^{1}$ XAVIER, Maria Elizabete S. P.; RIBEIRO, Maria Luísa Santos; NORONHA, Olinda Maria. História da educação: a escola no Brasil. São Paulo: FTD, 1994, p. 52.

${ }^{2}$ BOVE, Luiz Antonio. Uma Visão Histórica do Ensino Jurídico no Brasil. Revista do Curso de Direito, São Paulo, v. 3, n. 3, p. 115-138, 2006. Disponível em: <http://www.bibliotekevirtual.org/revistas/MetodistaSP/RCD/v03n03/v03n03a06.pdf> Acesso em: 20 maio 2016, p. 118.

${ }^{3}$ BOVE, Luiz Antonio. op. cit., p. 120.
} 


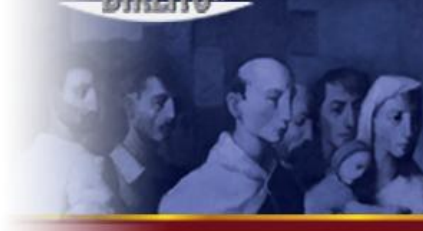

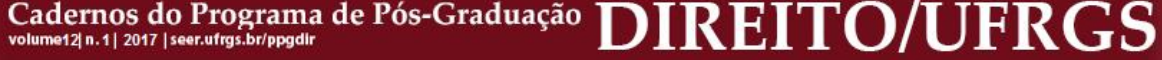

juristas ou políticos, decorriam de pessoas autodidatas, em razão da distância existente entre docente e discente. ${ }^{4}$

Conforme se pode verificar das matrizes curriculares iniciais, o estilo de ensinar no período imperial era jusnaturalista e eclesiástico e não se primava pelo desenvolvimento do senso crítico, posto que as preocupações se voltavam à sustentação do Estado e à formação de agentes que pudessem ocupar os diversos cargos criados nesta nova estrutura. ${ }^{5}$

Os cursos jurídicos criados se destinavam, portanto, a formação de uma "elite burocrática" que era preparada não para o exercício da advocacia ou para a discussão de demandas sociais, mas para a ocupação dos cargos públicos. ${ }^{6}$

O cenário aparentemente começa a ser alterado a partir da Proclamação da República, onde é possível verificar pequenas mudanças sendo realizadas no que diz respeito aos currículos dos cursos jurídicos, com a inserção de disciplinas que trabalhavam o senso crítico do estudante, como a substituição de cadeiras de direito eclesiástico e de direito natural, por filosofia do direito. ${ }^{7}$

Consoante versa Reale Júnior, a partir da década de 1930, buscou-se uma qualificação maior por parte dos docentes da área, com a realização de concursos para a obtenção de grau de doutor. Todavia, esta qualificação se mostrou limitada a poucas Faculdades, diante do crescimento de instituições privadas que ofertavam o curso, sem possuírem corpo docente e materiais capazes de formar indivíduos com visão crítica. $^{8}$ Nesta esteira preleciona Sant'Anna:

A realidade tem mostrado que boa parte dos bacharéis recém-formados não iniciarse-ão na profissão. A maioria tem em mente tentar um concurso público, já que a profissão dá essa amplitude. Pode-se tentar carreira na Advocacia da União, bem como no Ministério Público, Defensoria Pública, Judicatura, Procuradoria, na esfera policial e uma série de outras opções. Essa amplitude faz o curso ser muito heterogêneo, já que a maioria do corpo discente não tem o compromisso de questionar qual é o papel crítico do profissional do Direito na sociedade. Aceita-se

\footnotetext{
${ }^{4}$ WOLKMER, Antônio Carlos. Fundamentos de história do direito. 8. ed., rev. e ampl. Belo Horizonte: Del Rey, 2014, p. 491.

${ }^{5}$ LOPES, José Reinaldo de Lima. O direito na história: lições introdutórias. São Paulo: Max Limonad, 2011, p. 211.

${ }^{6}$ REALE JÚNIOR, Miguel. Criação e Degenerescência do Ensino Jurídico. Revista USP, São Paulo, n. 100, p. 87-96, 2013-2014. Disponível em: < http://www.revistas.usp.br/revusp/article/view/76171>. Acesso em: 20 maio 2016, p. 90.

7 BRASIL. Decreto $\mathrm{n}^{\mathrm{o}} 1232 \mathrm{H}$, de 2 de janeiro de 1891. Rio de Janeiro, 1891. Disponível em: <http://www.camara.gov.br/Internet/InfDoc/novoconteudo/Legislacao/Republica/LeisOcerizadas/1891dgpjan.pdf>. Acesso em: 22 maio 2016.

${ }^{8}$ REALE JÚNIOR, Miguel. op. cit., p. 93.
} 


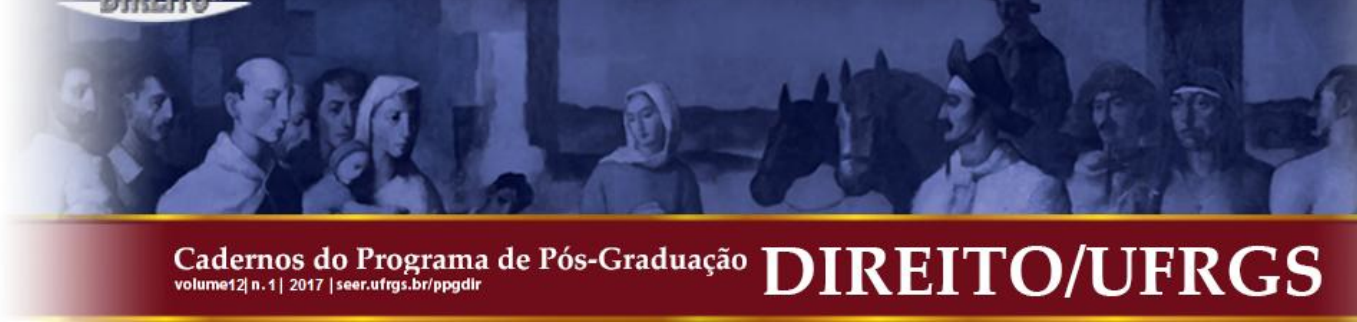

tudo o que os velhos mestres mandam sendo uma infinidade de Leis, Códigos Tratados e Decretos que muitas vezes pouco ou nada tem a ver com a realidade social que é mostrada na prática do cotidiano da profissão. ${ }^{9}$

Sant'Anna afirma ainda que os cursos começaram a proliferar para as capitais dos Estados e posteriormente foram sendo criados nos grandes centros urbanos. Diante desta proliferação, o pensamento que era ligado à retórica, ao positivismo e ao aspecto formal "foi se desenvolvendo de forma pouco didática através de décadas, já que a figura do mestre encarnava a figura do próprio saber, que não poderia ser objeto de questionamento". ${ }^{10}$

Iniciou-se no ano de 1950 o mesmo movimento ocorrido outrora, qual seja, o da reformulação do sistema de ensino superior o que culminou dez anos depois, aos 20 de dezembro de 1961, com a promulgação da Lei n. 4.024, tida como Lei de Diretrizes e Bases da Educação Nacional (LDB). ${ }^{11}$

De modo diverso da reforma ocorrida nos anos 30, a LDB se preocupou em regulamentar as formas de expansão do ensino superior, criando "três órgãos que poderiam decidir acerca da criação de novos cursos: as universidades que gozavam de autonomia; os Conselhos Estaduais de Educação e o Conselho Federal de Educação". ${ }^{12}$

Segundo Bastos, a referida lei foi o documento referência do período da modernidade, sendo a primeira normativa a definir os princípios educacionais básicos, as competências de cada setor, bem como quais autoridades estariam destinadas a colocá-la em prática. ${ }^{13}$

Em abril de 1963, por sua vez, promulga-se a Lei n. $4.215^{14}$, que reforma o Estatuto da Ordem dos Advogados do Brasil, institui o Exame da Ordem, bem como regulamenta a profissão de advogado e o estágio profissional. Alguns anos mais tarde, em 11 de novembro de 1968 institui-se a reforma universitária através da Lei n. $5.540^{15}$.

Segundo versava o art. 53 da referida lei, o Exame da Ordem era obrigatório somente para os candidatos que não tivessem feito estágio profissional ou não tivessem comprovado de forma satisfatória o seu exercício e resultado. Além disso, a prova era feita perante uma

\footnotetext{
9 SANT'ANNA, Sérgio Luiz Pinheiro. Crítica e reflexão sobre o ensino jurídico no Brasil - considerações acerca do papel do advogado nas transformações sociais dentro de uma visão histórica e política. Anais da Conferência Nacional da Oab, 13, Belo Horizonte. Brasília: OAB, 1990, p. 402.

${ }^{10}$ SANT'ANNA, Sérgio Luiz Pinheiro. op. cit., p. 404-405.

${ }^{11}$ SAMPAIO, Helena. O ensino superior no Brasil: o setor privado. São Paulo: Hucitec, 2000, p. 54-55.

12 SAMPAIO, Helena. op. cit., p. 55.

${ }_{13}$ BASTOS, Aurélio Wander. O ensino jurídico no Brasil. Rio de Janeiro: Lumen Juris, 1998, p. 227.

14 BRASIL. Lei $\mathrm{n}^{\mathrm{o}} 4.215$, de 27 de abril de 1963. Brasília, 1963. Disponível em: <http://www.planalto.gov.br/ccivil_03/leis/1950-1969/L4215.htm>. Acesso em: 22 maio 2016.

15 BRASIL. Lei $\mathrm{n}^{\mathrm{o}} 5.540$, de 28 de novembro de 1968. Brasília, 1968. Disponível em: <http://www.planalto.gov.br/ccivil_03/leis/L5540.htm>. Acesso em: 22 maio 2016.
} 


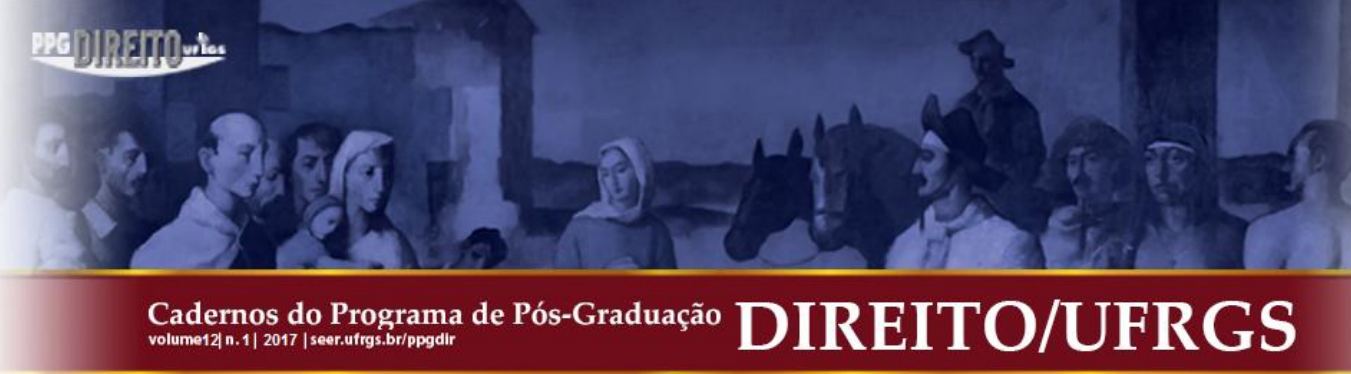

comissão composta de três advogados inscritos há mais de cinco anos, nomeados pelo Presidente da Seção, sendo dispensados do Exame os Magistrados, os membros do Ministério Público e os Professores das Faculdades de Direito oficialmente reconhecidas, que tivessem exercido as respectivas funções por mais de dois anos.

Venâncio Filho afirma que:

Deste período até 1972 não houve muitas mudanças qualitativas e nem estruturais nos currículos de Direito. As reformas existentes foram no sentido de dar um caráter mais profissionalizante ao curso, permanecendo a rigidez curricular, o baixo nível de qualidade, conteúdo desvinculado da realidade social e as tradicionais aulas por conferência. ${ }^{16}$

O marco de referência se dá, no entanto, com a promulgação da Constituição Federal de 1988, onde se estabeleceu em seu artigo 127 que "as universidades gozam de autonomia didático-científica, administrativa e patrimonial e obedecerão ao princípio da indissociabilidade entre ensino, pesquisa e extensão".

De forma complementar a Lei de Diretrizes de Bases, agora na Lei n. 9.394, de 20 de dezembro de 1996, em seu artigo 52 dispunha que "as universidades são instituições pluridisciplinares de formação dos quadros profissionais de nível superior de pesquisa, de extensão e de domínio e cultivo do saber humano":

As indicações da Constituição Federal e da LDB [Lei n. 9.394/1996] propõem marcos normativos abertos, aptos para a adaptação do ensino jurídico às exigências da sociedade. Esta sintonia legislativa deve ser operada por meio de normativa complementar, a cargo do Ministério da Educação-MEC, a quem cabe implementar as políticas tendentes à consecução dos parâmetros indicados na Constituição e na LDB. $^{17}$

No que diz respeito ao ensino jurídico, a Carta Magna de 1988 fortaleceu o papel da Ordem dos Advogados do Brasil (OAB), que passou a ter um papel mais ostensivo, o que influenciou a promulgação do novo Estatuto da Advocacia e da Ordem dos Advogados do Brasil em 1994 (Lei n. 8.906/94 ${ }^{18}$ ).

O novo currículo para o ensino jurídico brasileiro se deu, por sua vez, no decorrer do mesmo ano, através da Portaria MEC n. 1.886, ficando estruturado da seguinte maneira:

\footnotetext{
${ }^{16}$ VENÂNCIO FILHO, Alberto. Das Arcadas ao Bacharelismo. 2. ed. São Paulo: Perspectiva, 1982, p. 332.

17 BEZERRA, Francisco Otávio de Miranda. Ensino Jurídico numa perspectiva cidadã: interação social e políticas públicas. 2006. 236 f. Dissertação (Mestrado em Políticas Públicas) - Universidade Estadual do Ceará, 2006 , p. 72-73.

18 BRASIL. Lei $\mathrm{n}^{\text {o }} 8.906$, de 4 de julho de 1994. Brasília, 1994. Disponível em: <http://www.planalto.gov.br/ccivil_03/leis/L8906.htm>. Acesso em: 22 maio 2016.
} 
Inciso I, do artigo 60: Fundamentais: Introdução ao Direito; Filosofia (geral e jurídica, ética geral e profissional); Sociologia (geral e jurídica); Economia e; Ciência Política (com Teoria do Estado); Inciso II, do artigo $6^{\text {o: }}$ Profissionalizantes: Direito Constitucional; Direito Civil; Direito Administrativo; Direito Tributário; Direito Penal; Direito Processual Civil; Direito Processual Penal; Direito do Trabalho; Direito Comercial e; Direito Internacional.

Conforme observa Bastos, a portaria procurou superar as críticas referentes ao ensino jurídico desqualificado, deixando visível "a relevância de conhecimento interdisciplinar e da formação prática, coordenada entre os estudos práticos internos e as exigências da OAB, abrindo o curso de Direito para novas conexões institucionais de intercâmbio". ${ }^{19}$

Caminhando para um currículo que apresenta uma tentativa de se adequar as demandas sociais existentes no país, em setembro de 2004, instituiu-se as Diretrizes Curriculares Nacionais do curso de Direito, através da Resolução n. 9 do CNE/CES, que se encontra vigente até hoje. ${ }^{20}$

Neste sentido, verifica-se a preocupação com a integração entre os saberes na referida resolução, tendo em vista o estabelecimento do eixo de formação fundamental (artigo $5^{\circ}$, inciso I), onde são estipuladas disciplinas que se relacionem com outras áreas do saber; do eixo de formação profissional (artigo $5^{\circ}$, inciso II), onde deverão ser abarcadas disciplinas de cunho dogmático, incluindo-se estudos que acompanham as mudanças sociais e a evolução do Direito, bem como do eixo da formação prática (artigo $5^{\circ}$, inciso III), onde se objetiva a integração entre a prática e os conteúdos teóricos dos outros dois eixos.

Desta feita, atualmente os cursos jurídicos brasileiros devem possuir em seus currículos disciplinas que abranjam conteúdos essenciais de Antropologia, Ciência Política, Economia, Ética, Filosofia, História, Psicologia e Sociologia (eixo fundamental), Direito Constitucional, Direito Administrativo, Direito Tributário, Direito Penal, Direito Civil, Direito Empresarial, Direito do Trabalho, Direito Internacional e Direito Processual (eixo profissionalizante) e; Estágio Curricular Supervisionado, Trabalho de Curso e Atividades Complementares (eixo prático).

Entretanto, não obstante as diretrizes acima e suas intenções integrativas, o resultado prático de tudo isso não tem saído como o esperado. O número exagerado de cursos de Direito

\footnotetext{
${ }^{19}$ BASTOS, Aurélio Wander. O ensino jurídico no Brasil. Rio de Janeiro: Lumen Juris, 1998, p. 233-328.

20 BRASIL. Resolução CNE/CES no 9, de 29 de setembro de 2004. Brasília, 2004. Disponível em: <http://portal.mec.gov.br/cne/arquivos/pdf/rces09_04.pdf >. Acesso em: 22 maio 2016.
} 


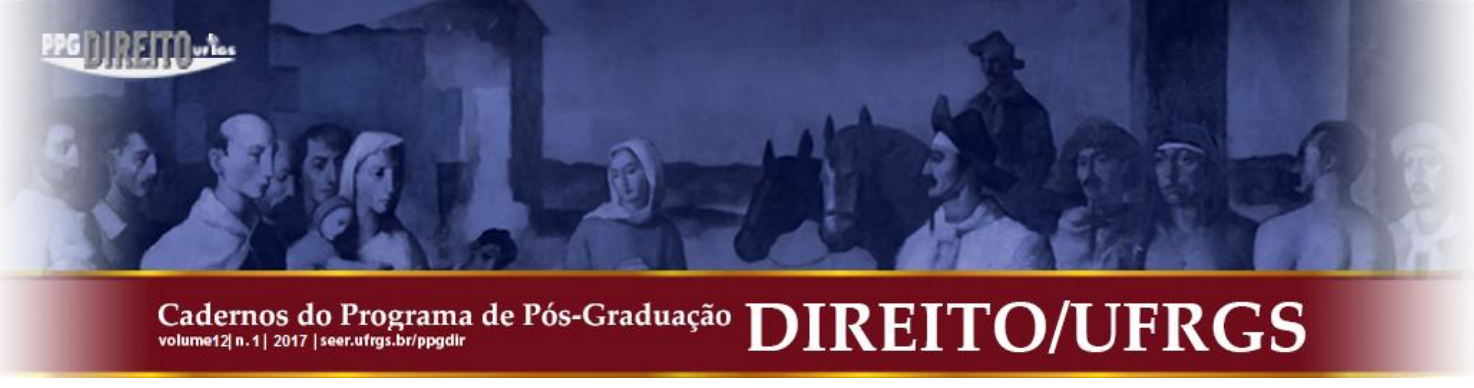

no país (existem cadastrados junto ao Ministério da Educação 1260 instituições com ensino jurídico $^{21}$ ), a falta de comprometimento educacional de diversas instituições (muitas vezes mais interessadas nas possibilidades mercantis e lucrativas dos cursos), aliada a uma fiscalização deficitária por parte dos órgãos competentes têm gerado resultados nefastos no mundo jurídico, tanto na inserção dos bacharéis no mercado de trabalho quanto em seu papel de artífices das mudanças sociais.

Estes fatos refletem inclusive no Exame da Ordem. Segundo dados publicados pela Fundação Getúlio Vargas Projetos em parceria com o Conselho Federal da Ordem dos Advogados do Brasil, das últimas dezesseis edições do Exame da Ordem Unificado aplicadas no país, obteve-se 1,91 milhão de inscrições, 639 mil participantes com CPFs diferentes e apenas 360 mil aprovados na segunda fase. ${ }^{22}$

Fala-se, então, em uma crise do ensino jurídico - e consequentemente da advocacia que, segundo Aguiar, decorre, dentre outros, de problemas conceituais, que se desdobram em epistêmicos, antropológicos e educacionais, posto que o conteúdo transmitido não se coaduna com a realidade científica e social da época, o indivíduo é visto como algo abstrato, normativo e isolado da historicidade, o que reflete em estudos baseados em uma antropologia morta, com inúmeras instituições capazes de formar somente técnicos manipuladores de conteúdos normativos postos. $^{23}$

De modo convergente é o pensamento de Lôbo, que afirma ser o exegetismo a característica mais evidente do estado de "desqualificação e distanciamento científico" que os cursos jurídicos chegaram:

O exegetismo, nos cursos jurídicos, é o símbolo maior do estado de desqualificação e distanciamento científico a que chegaram. Deixar-se de ensinar o direito para ensinar (e mal) a lei, através de comentários que tocam as raias da evidência ou fazendo uso freqüente [sic] de argumento de autoridade. Desenvolve-se, pela inércia, um tipo pobre de raciocínio jurídico, delimitado pelo legalismo positivista, que marcará $\backslash$ o desempenho profissional dos futuros advogado, magistrado ou promotor de justiça, os quais não terão pejo de afirmar-se "escravos da lei". Assiste-se a um tácito pacto de omissões: de um lado, o professor dá pouco e cobra pouco e, de

\footnotetext{
${ }^{21}$ INSTITUIÇÕES de Educação Superior e Cursos Cadastrados. Disponível em: <http://emec.mec.gov.br/>. Acesso em: 24 maio 2016.

${ }^{22}$ EXAME de Ordem em números. v. III. Disponível em: < http://fgvprojetos.fgv.br/publicacao/exame-deordem-em-numeros-vol3>. Acesso em: 15 ago. 2016.

${ }^{23}$ AGUIAR, Roberto Alberto Ramos de. A Crise da Advocacia no Brasil. Anais da Conferência Nacional da Oab, 13, Belo Horizonte. Brasília: OAB, 1990, p. 447.
} 
outro, o aluno recebe menos e é menos exigido, porque seu objetivo não é aprender, mas obter o diploma. ${ }^{24}$

Soma-se à ocorrência de um ensino jurídico incapaz de formar profissionais com pensamento crítico, o fato de que, o Direito, como técnica de controle, vem sendo diariamente desprestigiado pela sociedade. A atuação ética tem sido substituída por formas mais eficientes e rápidas de se promover o que se parece ser o bem comum, ou seja, é possível que se atue fora do Direito e, somente diante de um conflito, utilize-se o julgamento dos tribunais. ${ }^{25}$

Segundo Dantas, isso advém da perda de confiança no Direito, como técnica de controle social:

\begin{abstract}
Todas essas atitudes procedem de uma perda crescente de confiança no Direito, como técnica de controle social. Ora, essa perda de confiança envolve, em suas últimas consequiências [sic], a contestação, ainda que no terreno intelectual, da supremacia da ordem jurídica, e a determinação dos fins da atividade social através de critérios estritamente pragmáticos ou políticos emancipados de toda sujeição ao Direito. Considerada no campo histórico da civilização ocidental, a que pertence, ela subverte as aspirações permanentes de nossa cultura, e marca, melhor do que qualquer outra, a sua reorientação no sentido da destruição. ${ }^{26}$
\end{abstract}

Vale ressaltar que, em razão da predominância de disciplinas dogmáticas no curso, acaba-se por instrumentalizar o próprio cientista jurídico, chamado de operador do direito, como se fosse um profissional técnico, “cujo acesso ao Direito se faz somente pelo manejo de ferramentas - regras de interpretação - sem as quais não tem como realizar seu trabalho, que desempenha depois de aceitar os pontos de partida (dogmas) estabelecidos pela escola jurídica"27.

É sob este aspecto que se identifica a necessidade de um saber integral, com a aplicação de disciplinas dogmáticas que se relacionem de modo interdependente com outras áreas do conhecimento, tal qual é proposto na Resolução n. 9 do $\mathrm{CNE} / \mathrm{CES}^{28}$. Isso porque,

\footnotetext{
${ }^{24}$ LÔBO, Paulo Luiz Neto. Ensino jurídico: ensino jurídico na atualidade brasileira. Anais da Conferência Nacional da Oab, 13, Belo Horizonte. Brasília: OAB, 1990, p. 379.

${ }^{25}$ DANTAS, Francisco Clementino de San Tiago. A Educação Jurídica e a Crise Brasileira. Rio de Janeiro: Escola de Direito do Rio de Janeiro da Fundação Getúlio Vargas, 2010, p. 9-37; DANTAS, Francisco Clementino de San Tiago. A Educação Jurídica e a Crise Brasileira. Cadernos FGV Direito Rio, Educação e Direito, v.3, 2009, p. 15-16.

${ }^{26}$ DANTAS, Francisco Clementino de San Tiago. A Educação Jurídica e a Crise Brasileira. Cadernos FGV Direito Rio, Educação e Direito, v.3, 2009, p. 15-16.

${ }^{27}$ NUNES, Rizzatto. Manual de introdução ao estudo do direito: com exercícios para sala de aula e lições de casa. 9. ed. São Paulo: Saraiva, 2009, p. 60.

28 BRASIL. Resolução CNE/CES n 9, de 29 de setembro de 2004. Brasília, 2004. Disponível em: <http://portal.mec.gov.br/cne/arquivos/pdf/rces09_04.pdf >. Acesso em: 22 maio 2016.
} 


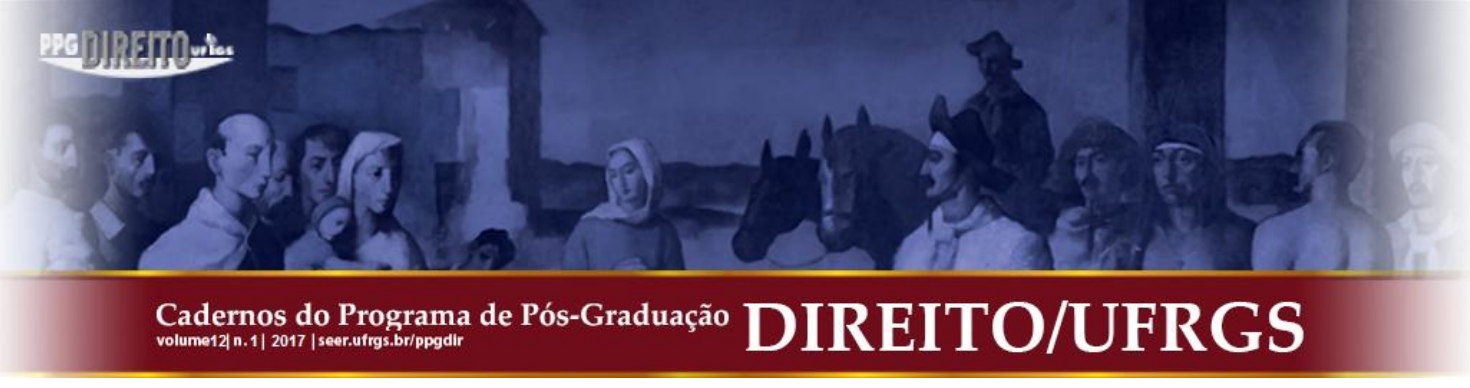

ainda que haja uma preocupação de que o estudante deve ter acesso total ao acervo da humanidade, muitas instituições ainda o transmitem de forma fragmentada.

Neste sentido, a revisão dos paradigmas jurídicos que tratam da sociedade se mostra imprescindível diante do ritmo frenético que caracteriza a sociedade pós-moderna e isto somente é possível através do conhecimento da filosofia, da ciência política, da sociologia, dentre outras, sob pena de se formarem profissionais que são meros reprodutores burocráticos das interpretações das normas jurídicas existentes. ${ }^{29}$

\section{AS MUDANÇAS SOCIAIS E AS EXIGÊNCIAS JURÍDICAS ATUAIS}

Partindo-se da premissa que a ciência do Direito decorre de operações valorativas ou axiológicas é possível verificar que a ideia de Direito, a metodologia e a forma como ele ocorre, são totalmente condicionados pela sociedade. Sendo uma realidade histórico-cultural, os princípios, a moral e todos os acontecimentos que moldam a vida em comunidade, influenciam as normas que são criadas pelos legisladores.

Em que pese claramente encerrar esse conteúdo axiológico, o Direito, principalmente no período moderno, era abordado de uma forma a ocultar os seus aspectos valorativos, tendo em vista a prevalência do normativismo e do positivismo, onde a maneira de se conhecer o fenômeno jurídico se dava aplicando de forma asséptica a norma ao fato ocorrido em sociedade. ${ }^{30}$

Construído sobre princípios filosóficos modernistas, o Direito da idade moderna apresentava um caráter universal na solução dos conflitos, com predominância na razão. A lei, portanto, era votada em nome de todos e deveria ser aplicada de forma igualitária, posto que supostamente representava uma garantia suprema contra o arbítrio de determinados grupos sociais, econômicos ou políticos. ${ }^{31}$

Ocorre que, em verdade, tinha-se um Direito estatal, centralizado e previsível, onde a força e a coação utilizada pelo Estado constrangia ou induzia à obediência de condutas a

\footnotetext{
${ }^{29}$ AGUIAR, Roberto Alberto Ramos de. op. cit., p. 449.

${ }^{30}$ MACHADO, Antônio Alberto. Ensino Jurídico e Mudança social. 2. ed. São Paulo: Atlas, 2009, p. 15-16.

${ }^{31}$ ARNAUD, André Jean. O direito traído pela filosofia. Porto Alegre: Sergio Antonio Fabris, 1991, p. 246. 


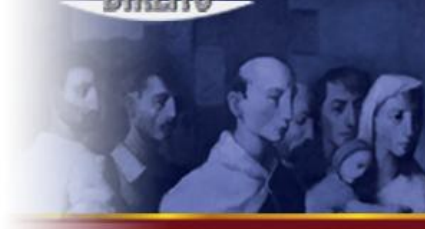

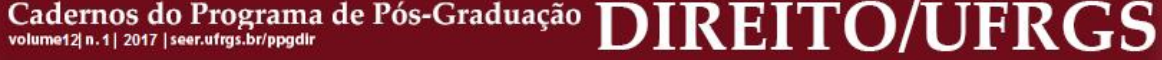

serviço das instituições em geral, estruturando-se em um complexo de normas de teor geral, abstrato, coercível e impessoal. ${ }^{32}$

Um exemplo claro da ocorrência destas características na sociedade em geral, foi a forma de manutenção do poder nos estados modernos. Tendo a força e a violência como elementos secundários - posto que a manipulação do pensamento dos indivíduos e a mobilização espiritual eram os principais modos de coerção - subordinou-se quase totalmente a moralidade à política. Toda conduta "condensou-se, institucionalizou-se e fundiu-se com os poderes legais do estado político. Expropriou-se a capacidade moral, e tudo o que resistisse à estatização era perseguido com todo o rigor da Lei”. 33

Devido a estas características, o Direito funcionava ao contrário do almejado, pois se mostrava como uma legalização de interesses de grupos determinados, o que caracterizava, em verdade, uma desigualdade, onde a classe dirigente estabelecia suas aspirações, objetivos e valores sob as classes populares e menos favorecidas. ${ }^{34}$

Nesta esteira, afirma Lopes:

A matéria que domina a jurisprudência [meados de 1870], como não poderia deixar de ser, é o assunto das classes possuidoras: heranças, compras e vendas de terras, forma de tratamento de escravos, negócios societários e circulação de mercadorias e títulos. [...] Outras questões frequentes diziam respeito a falências e concordatas e a substituição de sócios seja por herdeiros, seja por outros sócios. ${ }^{35}$

Assim, as demandas jurídicas se limitavam a solucionar conflitos relacionados exclusivamente à vida privada, consubstanciados principalmente no direito de propriedade, das sucessões e das obrigações, em razão da influência sofrida pelo direito romano e germânico. $^{36}$

No que diz respeito a tal influência, desde a antiguidade as populações da Grécia e Roma reconheceram e praticaram a propriedade privada, ainda que baseadas em princípios diferentes dos aplicados posteriormente. Do direito à propriedade, inclusive, decorreu o direito das sucessões, surgido também entre os antigos. Conforme dispõe Coulanges, "o direito da propriedade, tendo-se estabelecido para a perpetuação de um culto hereditário, não

\footnotetext{
${ }^{32}$ WOLKMER, Antonio Carlos. História do Direito no Brasil. 8. ed., rev. e atual. Rio de Janeiro: Forense, 2015. 2015, p. 42.

${ }^{33}$ BAUMAN, Zygmunt. Ética pós-moderna. São Paulo: Paulus, 1997, p. 195.

${ }^{34}$ MACHADO, Antônio Alberto. Ensino Jurídico e Mudança social. 2. ed. São Paulo: Atlas, 2009, p. 15-16.

${ }^{35}$ LOPES, José Reinaldo de Lima. O direito na história: lições introdutórias. São Paulo: Max Limonad, 2011, p. 311-312.

${ }^{36}$ NASCIMENTO, Walter Vieira do. Lições de história do direito. 15. ed., rev. e aum. Rio de Janeiro: Forense, 2004 , p. 143
}

Cadernos do Programa de Pós-Graduação em Direito PPGDir./UFRGS | Edição Digital | Porto Alegre | Volume XII| Número 1 | 2017 | P.136 - 165 


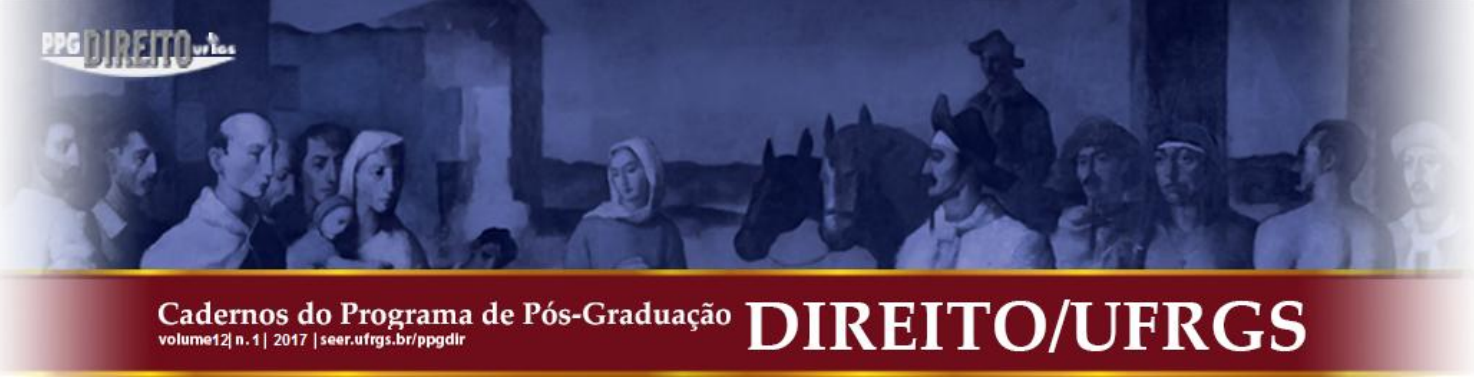

podia desaparecer ao longo da existência de um indivíduo" o que ensejou o surgimento da herança e, por consequência, o direito de sucessão. ${ }^{37}$

Da mesma forma, o direito moderno regulava, no que diz respeito ao direito da propriedade, institutos como o das servidões, o do poder marital, o das sucessões, o da comunhão entre marido e mulher. No âmbito do direito das coisas, abordavam-se, a título de exemplo, aspectos relacionados à proteção possessória dos direitos pessoais e no direito das obrigações, aos direitos e deveres advindos de negócios jurídicos firmados entre as partes. ${ }^{38}$

Sobre estas características elucida Wolkmer:

O primeiro grande instituto da juridicidade moderna é o direito de propriedade, simbolizando uma forma de poder qualificado como absoluto, exclusivo e perpétuo. [...] O contrato é outro símbolo máximo do poder da vontade individual numa estrutura sócio-econômica capitalista. O exacerbado individualismo da livre contratação e da autonomia da vontade funciona através do chamado negócio jurídico, um "instrumento de auto-regulamentação dos interesses dos particulares", que não deixa de ocultar a desigualdade real. ${ }^{39}$

Tomando por base os institutos citados é possível perceber que, em que pese o equívoco em utilizar-se tão somente do normativismo positivista à resolução de conflitos, a complexidade das demandas jurídicas travadas no período moderno não ensejava uma valoração constante dos aspectos antropológicos, econômicos, sociológicos, políticos, éticos e históricos da sociedade, bastando para tanto, uma mera adequação do fato à norma. ${ }^{40}$

No entanto, o rápido desenvolvimento das sociedades, assinalado pelos avanços econômicos, sociais e tecnológicos, evidenciaram que a simples adequação jurídica do fato ocorrido na sociedade não era suficiente à resolução de demandas, que se mostravam cada vez mais complexas:

Os dilemas de uma sociedade em intenso processo de modificação, onde o novo é
sempre substituído pelo mais novo, onde o velho é aquilo que há pouco era recente,
são inúmeros. Paranoias coletivas, comportamentos estandardizados, desejos
homogeneizados, excesso de informação moral desenraizada e desconexa,
pluralismo de tendências éticas mal definidas, reações éticas inexplicáveis, cisão
com a tradição, negação ostensiva do passado, perda de registros éticos e referências
dogmáticas, desorientação moral, perda da noção da origem do mal moral, aceitação
de tudo indiferença para com o outro, permissividade, contestação frenética de toda
autoridade, difusão de cultos de duvidável credibilidade, de seitas apocalípticas, de

${ }^{37}$ FUSTEL DE COULANGES. A cidade antiga: estudo sobre o culto, o direito as instituições da Grécia e da Roma. Tradução de Jonas Camargo Leite e Eduardo Fonseca. São Paulo: Hemus, 1975, p. 49-58.

${ }^{38}$ NASCIMENTO, Walter Vieira do. op.cit., 2004, p. 146.

${ }^{39}$ WOLKMER, Antonio Carlos. História do Direito no Brasil. 8. ed., rev. e atual. Rio de Janeiro: Forense, 2015, p. 43-44.

40 ARNAUD, André Jean. O direito traído pela filosofia. Porto Alegre: S. A. Fabris, 1991, p. 245. Cadernos do Programa de Pós-Graduação em Direito PPGDir./UFRGS | Edição Digital | Porto Alegre | Volume XII| Número 1 | 2017 | P.136 - 165 
grupos fanáticos, de religiões oportunistas, carência de divisas entre valores, entre o certo e o errado, são apenas alguns dos dilemas sentidos e vividos por cada indivíduo pós-moderno. ${ }^{41}$

Soma-se a isso as consequências advindas da Segunda Guerra Mundial, uma vez que diante da flagrante hostilidade para com os povos, da intolerância, da perseguição, da repressão e de demonstrações de clausura moral, emergiram-se direitos difusos, coletivos e sociais, com características eminentes de direito público, contrapondo-se diretamente com o direito privado aplicado até então. ${ }^{42}$

Demais disso, ressalta-se que, os poderes coercitivos do estado moderno acarretaram uma original característica da idade pós-moderna: “que o estado não mais tem capacidade, necessidade nem vontade de liderança espiritual (incluindo isso a moral). $\mathrm{O}$ estado 'deixa correr', de propósito ou por omissão, os poderes contraestruturais da socialidade". Tal fato se dá, em parte, pela experiência tida com os estados totalitários, onde a moral e o estado político se confundiam. ${ }^{43}$

A problemática do mundo pós-moderno atinge, portanto, o pensamento e as práticas morais em todos os aspectos da sociedade, transformando, além de tudo, as relações mais íntimas dos indivíduos. Privilegia-se a heterogeneidade e o pluralismo, como modos de libertação da cultura e da totalidade, apostando na fragmentação de sistemas, na indeterminação, na descontinuidade e na alteridade dos indivíduos, o que caracteriza a opção pela contingência. A indeterminação se torna a definição e o modo de liberdade, todavia, esta definição não é de todo fornecida, mas apenas sugerida pelo pós-modernismo, tendo em vista que tentar definir tal característica, seria voltar-se para o universal. ${ }^{44}$

Vê-se, assim, que tanto no plano histórico quanto no social, o direito enfrentou uma revisão e uma transformação de seus institutos, projetando-se em uma dimensão pública e transindividual, até mesmo no âmbito do direito privado, visto que este vem apresentando uma intensa interdisciplinaridade com o direito público.

Lôbo afirma que, no ordenamento jurídico brasileiro, em razão da Constituição Federal de 1988 referir-se a direitos individuais e coletivos, tidos como direitos subjetivos,

\footnotetext{
${ }^{41}$ BITTAR, Eduardo C. B. Curso de ética jurídica: ética geral e profissional. 3. ed., rev. São Paulo: Saraiva, 2005, p. 81-82.

${ }^{42}$ BITTAR, Eduardo C. B. op. cit., p. 85.

${ }^{43}$ BAUMAN, Zygmunt. Ética pós-moderna. São Paulo: Paulus, 1997, p. 195.

${ }^{44}$ CHAUÍ, Marilena. Público, Privado, Despotismo. In: NOVAES, Adauto (Org.). Ética. São Paulo: Companhia das Letras, 2007, p. 505.
} 


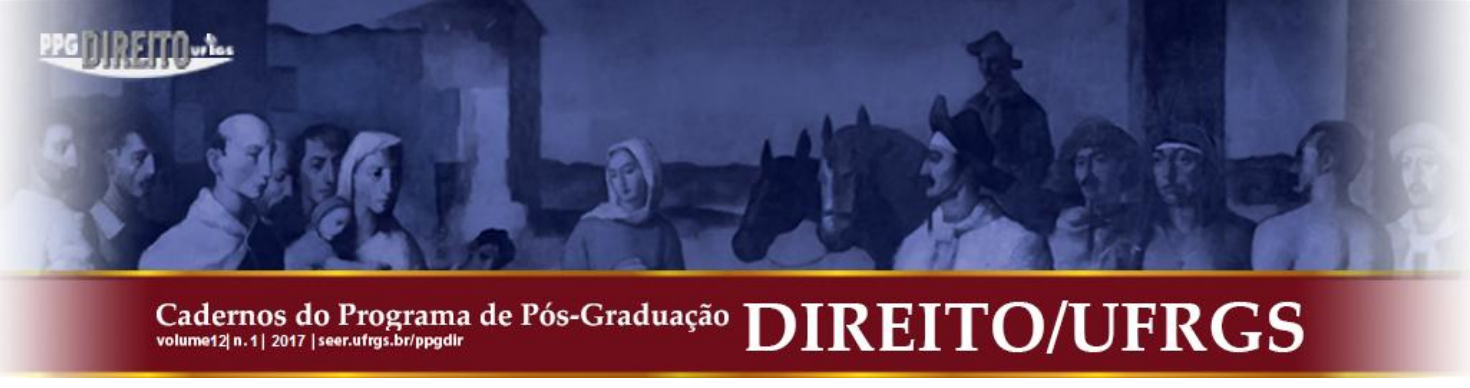

urbanos marginais, nas igrejas, nas empresas, no desporto, nas organizações profissionais. Trata-se de formas de direito infra-estatal [sic], informal não oficial e mais ou menos costumeiro". 50

Tem-se à frente, portanto, o que alguns nomeiam novos direitos e a complexidade destes exige uma profunda reflexão interdisciplinar, no sentido de compreender que o fenômeno jurídico possui vínculos entre os mais variados âmbitos da sociedade, como o da ética, o da política, o da economia, o da história:

[...] não há mais a juridicidade isolada, no mundo onde a informação é o poder e a interdisciplinaridade é uma necessidade. As normas jurídicas, em si mesmas consideradas, são vazias. É a sua interpretação ou sua derrogação por nova norma, que tem vida, e essa vida é dada por fatores transjurídicos de natureza social, política, econômica e cultural. Logo, se o advogado não conhecer da filosofia, da ciência política, da sociologia, dentre outras ciências, corre o risco de se tomar um reprodutor burocrático menor das interpretações dominantes relativas às normas jurídicas. Em suma há necessidade de um processo de revisão dos paradigmas que possibilite ao advogado tratar da sociedade, do estado e da democracia com outras lentes, sob pena de ser atropelado pelo ritmo frenético que caracteriza a sociedade pós-moderna. ${ }^{51}$

Tal interdisciplinaridade é claramente visível quando se analisa os casos complexos que o Supremo Tribunal Federal vem julgando, como por exemplo, a Ação Direta de Inconstitucionalidade 4277, que reconheceu a união entre pessoas do mesmo sexo como entidade familiar, o RE 201.819-9, que aborda a eficácia dos direitos fundamentais nas relações privadas, e a limitação que estas possuem frente a um direito que prima pela função social da propriedade ou a (in)constitucionalidade de pesquisas com células-tronco embrionárias, objeto da ADI 3510 e a ADPF 54, que trouxe a possibilidade da interrupção terapêutica da gravidez de fetos anencéfalos.

São inúmeras as decisões que se mostram totalmente diferentes das de outrora e as mudanças que vêm ocorrendo são nítidas, no sentido de que há uma profunda interação existente entre os diversos saberes sendo necessário, portanto, conhecê-los, para que seja possível julgar as demandas se pautando no bem comum da sociedade.

Todas essas demandas jurídicas abarcam situações complexas e profundas que alteram os conceitos de direito público e privado, de instituições familiares e da inviolabilidade e

\footnotetext{
${ }^{50}$ SANTOS, Boaventura de Souza. apud OAB. Conselho Federal. Ensino jurídico - OAB. Balanço de uma experiência. Brasília: OAB, 2000, p. 53.

51 AGUIAR, Roberto Alberto Ramos de. op. cit., p. 449.
} 


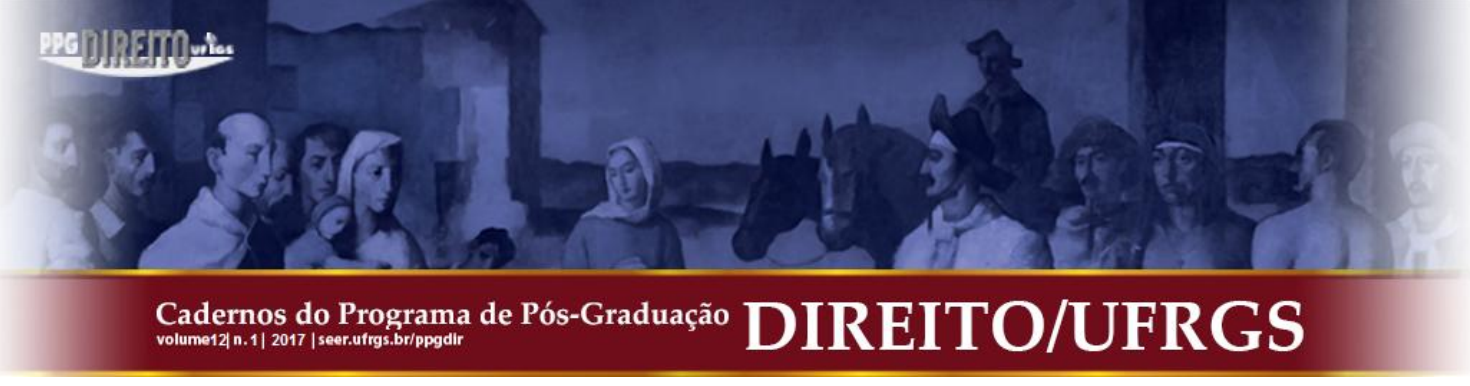

irrenunciabilidade dos direitos fundamentais, institutos estes que no decorrer da história do direito não existiam ou até mesmo se mantinham inalterados.

Assim, é possível evidenciar que em um mundo pós-moderno, diante desta nova postura adotada pelos tribunais, para que o estudante de Direito consiga buscar a solução de uma determinada demanda, se mostra imprescindível uma postura diferenciada, tendo em vista que a adequação do caso concreto à norma não é suficiente por si só à resolução das demandas jurídicas que se apresentam hodiernamente.

\section{O ENFOQUE ZETÉTICO E DOGMÁTICO DO FENÔMENO JURÍDICO}

O Direito pode ser classificado como uma ciência humana, que se destina à investigação da relação entre os indivíduos e suas ações. Para compreendê-las e explicá-las, se faz necessário tomar por base uma acepção valorativa. ${ }^{52}$ Montoro afirma se tratar de uma ciência normativa ética, humana ou moral, posto que "sua finalidade específica é ordenar a conduta social dos homens, para que cada um (indivíduo ou sociedade) tenha o que lhe é "devido" (dever-ser). ${ }^{53}$

O fato de o objeto de estudo ser o indivíduo e suas ações, torna o Direito peculiar às outras ciências, tendo em vista que a perquirição da norma jurídica não é suficiente à compreensão de tal, tornando necessário, além da investigação das causas da criação da norma e da sua adequação ao meio social, a análise dos fatos sociais e de seus aspectos sociológicos, econômicos, culturais, bem como dos valores éticos e morais relacionados a eles:

[...] tendo em vista as peculiaridades do objeto da Ciência do Direito, percebe-se que ela não tem de dar conta apenas das normas jurídicas e sua aplicação ou não, mas também tem de lidar com fatos sociais, aspectos sociológicos, econômicos, culturais e até climáticos, com diferenças regionais e territoriais, bem como com valores éticos e morais. Deve, ainda, investigar as causas de elaboração das normas jurídicas, em especial as leis, bem como sua adequação ao meio social. Todas essas normas e valores devem respeitar o homem em sua dignidade de ser humano, no meio social e na natureza em que vive. A Ciência do Direito em sua acepção mais ampla é uma ciência ética por excelência. ${ }^{54}$

\footnotetext{
${ }^{52}$ NUNES, Rizzatto. Manual de introdução ao estudo do direito: com exercícios para sala de aula e lições de casa. 9. ed. São Paulo: Saraiva, 2009, p. 30.

${ }_{53}$ MONTORO, André Franco. Introdução à ciência do direito. 5. ed. São Paulo: Martins, 1974, p. 95-96.

${ }^{54}$ NUNES, Rizzatto. op.cit., p. 51. 


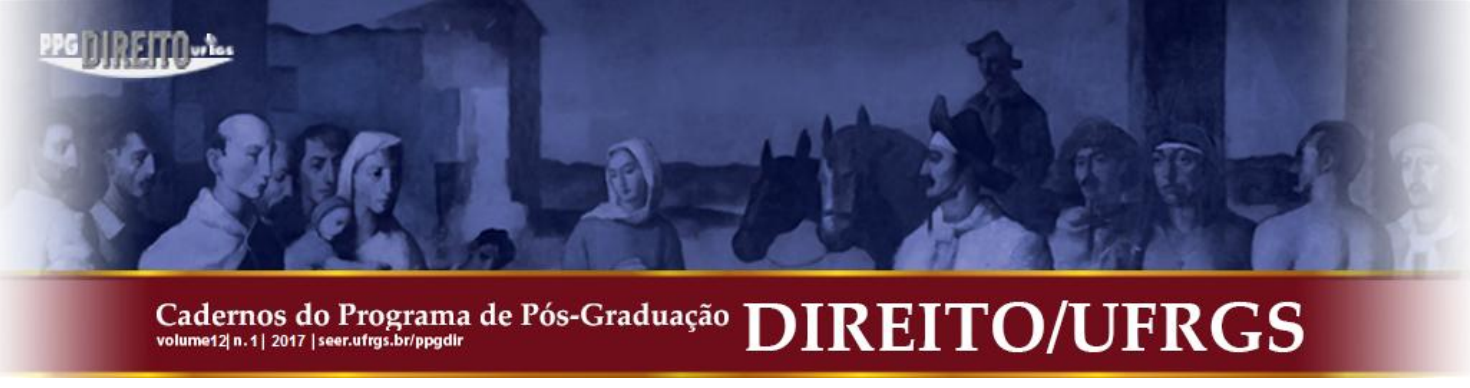

O estudo destes aspectos, por sua vez, pode se dar sob diferentes ângulos, uma vez que "o direito pode ser objeto de teorias básicas e intencionalmente informativas, mas também de teorias ostensivamente diretivas". Valendo-se da distinção utilizada por Ferraz Júnior, a análise pode se dar assim, através de um enfoque zetético ou de um dogmático. Os dois enfoques possuem características que os diferenciam de forma contundente, no entanto, em uma investigação sempre existirão os dois, podendo prevalecer ora o enfoque zetético, ora o dogmático. $^{55}$

Etimologicamente, a palavra zetética (zetein) significa perquirir e dogmática (dokein), possui o significado de ensinar, doutrinar. Assim sendo, a primeira revela um estudo baseado na dissolução de opiniões e fundamentos, colocando todo conceito e pressuposto em dúvida, possuindo uma função especulativa e infinita. Já a segunda, releva a opinião, partindo de pressupostos que, em um primeiro momento, são tidos como inatacáveis e insubstituíveis, “por isso, o enfoque zetético visa saber o que é uma coisa. Já o enfoque dogmático preocupase em possibilitar uma decisão e orientar a ação". 56

Tem-se assim que, a zetética parte de evidências e a dogmática, de dogmas. Para que a investigação ocorra, ambas devem pôr alguma coisa à dúvida; desta forma, enquanto a zetética deixa de questionar enunciados por admiti-los como verificáveis e comprováveis, a dogmática deixa de questionar as premissas, pois as considera estabelecidas como inquestionáveis. ${ }^{57}$

Assim, a zetética jurídica se dá, quando o fenômeno jurídico é estudado através de disciplinas como Sociologia, Antropologia, Psicologia, História, Filosofia, Ciência Política, entre outras:

\footnotetext{
Nessa perspectiva, o investigador preocupa-se em ampliar as dimensões do fenômeno, estudando-o em profundidade, sem limitar-se aos problemas relativos à decisão dos conflitos sociais, políticos, econômicos. Ou seja, pode encaminhar sua investigação para os fatores reais do poder que regem uma comunidade, para as bases econômicas e sua repercussão na vida sociopolítica, para um levantamento dos valores que informam a ordem constitucional, para uma crítica ideológica, sem preocupar-se em criar condições para a decisão constitucional dos conflitos máximos da comunidade. ${ }^{58}$
}

\footnotetext{
${ }^{55}$ FERRAZ JÚNIOR, Tércio Sampaio. Introdução ao estudo do direito: técnica, decisão, dominação. 6. ed. São Paulo: Atlas, 2008, p. 17.

${ }^{56}$ FERRAZ JÚNIOR, Tércio Sampaio. op. cit., p. 18.

${ }^{57}$ NUNES, Rizzatto. Manual de introdução ao estudo do direito: com exercícios para sala de aula e lições de casa. 9. ed. São Paulo: Saraiva, 2009, p. 60-61.

${ }^{58}$ FERRAZ JÚNIOR, Tércio Sampaio. op.cit., p. 21.
} 


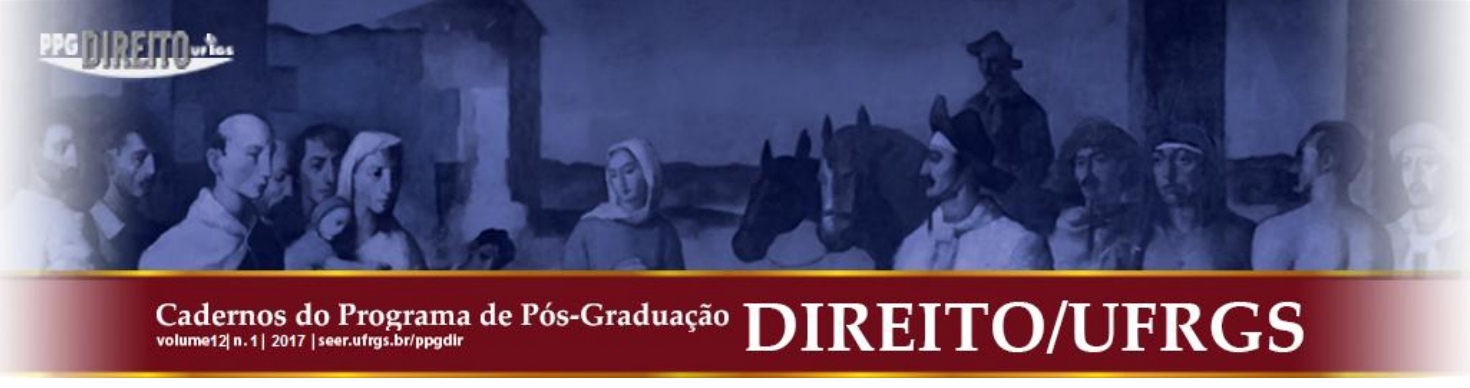

Em contrapartida, são tidas como disciplinas dogmáticas, o Direito Civil, Comercial, Constitucional, Processual, Penal, Tributário, Administrativo, entre outras. Isto se dá, em virtude da dogmática jurídica se concentrar em "esforços de generalização e sistematização sobre o que poderíamos chamar o direito positivo nacional e histórico, isto é, as regras emanadas do poder competente, em espaço e tempo determinados". 59

Neste sentido Nunes afirma que "bom cientista dogmático é aquele que incorporou os valores prévios e os modelos preexistentes, e é bom cumpridor das regras, que ele maneja com vistas a orientar a ação dos outros". ${ }^{60}$ Investigar o fenômeno jurídico pelo enfoque dogmático, portanto, é estar limitado, de uma certa forma, à exploração dos comportamentos juridicamente possíveis em uma determinada demanda.

Altamente influenciado pelo positivismo jurídico, o enfoque dogmático foi e ainda é predominante nas diversas Instituições de Ensino. Conforme vastamente abordado no decorrer deste trabalho, o estudo do Direito ainda é identificado como um tipo de estudo formalista e fechado, que se destina, na maioria das vezes, a atender somente as necessidades imediatas do juiz, do advogado, do promotor.

Tal característica, decorre em grande parte do método de ensino e por consequência das disciplinas que foram e são estudadas nas escolas. A instrumentalização do ensino jurídico brasileiro é muito claro quando se analisa as matrizes curriculares que existiram desde a criação dos cursos jurídicos. Somente após a criação da Lei das Diretrizes e Bases da Educação Nacional (promulgada em 1961) é que a matriz curricular base do curso começa a possuir traços de um ensino jurídico mais zetético. ${ }^{61}$

No entanto, a efetiva obrigatoriedade de disciplinas com enfoque zetético se deu apenas em 1994, através da Portaria n. 1.886 instituída pelo Ministério da Educação e do Desporto, que trouxe como disciplinas fundamentais a Filosofia, Sociologia, Economia e Ciência Política. ${ }^{62}$

É nítido, portanto, que a busca por um saber mais analítico ainda é muito recente na história brasileira. Apesar do pensamento crítico contemporâneo extrapolar os limites da lei e

\footnotetext{
${ }^{59}$ MATA-MACHADO, Edgar de Godoi da. Elementos de teoria geral do direito: para os cursos de introdução à ciência do direito. Belo Horizonte: Vega, 1972, p. 119-143.

${ }_{61}^{60}$ NUNES, Rizzatto. op.cit., p. 60.

61 BRASIL. Lei $\mathrm{n}^{\mathrm{o}}$ 4.024, de 20 de dezembro de 1961. Brasília, 1961. Disponível em: <http://www.planalto.gov.br/CCIVIL_03/leis/L4024.htm>. Acesso em: 22 maio 2016.

${ }^{62}$ BRASIL. Portaria Ministerial $\mathrm{n}^{\circ} 1.886$, de 30 de dezembro de 1994. Brasília, 1994. Disponível em: <http://www.migalhas.com.br/arquivo_artigo/art20100108-03.pdf>. Acesso em 03 abr. 2017.
} 


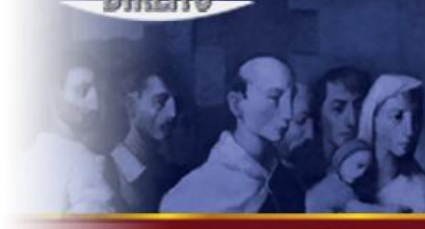

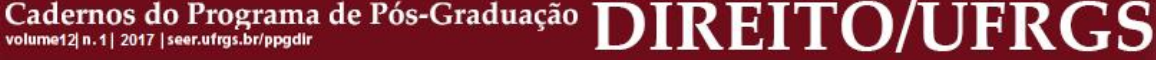

influir no campo social e valorativo, por ser influenciado pelo próprio meio social e pela linguagem utilizada ser antes política, do que científica, ainda há um amplo controle social:

Se instrumentaliza o próprio cientista jurídico, que passa a ser um técnico cujo acesso ao Direito se faz somente pelo manejo de ferramentas - regras de interpretação - sem as quais não tem como realizar seu trabalho, que desempenha depois de aceitar os pontos de partida (dogmas) estabelecido pela escola jurídica. ${ }^{63}$

Ocorre que, tomando por base a Teoria Tridimensional do Direito, que concebe o Direito como sendo uma estrutura composta por "um aspecto normativo (o Direito como ordenamento e sua respectiva ciência); um aspecto fático (o Direito como fato, ou em sua efetividade social e histórica) e um aspecto axiológico (o Direito como valor de Justiça)",64, o enfoque dogmático não pode ser o único utilizado para estudar o conjunto global da ciência do direito.

Filiando-se ao entendimento de Azevedo, o conhecimento da regra positivada, da sua hierarquização, dos conceitos fundamentais e dos princípios norteadores, são de suma importância, posto que não é possível solucionar um problema jurídico sem o adequado conhecimento destes institutos. No entanto, “o reconhecimento de sua relevância não importa em subscrever a orientação positivista que lhe é normalmente assinalada, de graves consequências sobre a concepção do direito e sérias projeções sociais" ${ }^{65}$

Isto porque, se o trabalho da dogmática jurídica se afastar da realidade social, operarse-á uma verdadeira manipulação ideológica:

Efetivamente, não pode o trabalho da Dogmática Jurídica ou Ciência Jurídica Positiva ser desligado da sociedade, a menos que, em nome de uma pretensa cientificidade, se aceite que deva girar sobre seu próprio eixo, afastando-se, dessa forma, da realidade mesma em função de que precisamente existe e se deve realizar. Assim se procedendo, embora se diga que se age em nome da "cientificidade" da Ciência do Direito, opera-se a sua manipulação ideológica. ${ }^{66}$

Diz-se ideológica porque os indivíduos, sem se darem conta ou sem terem consciência, julgam-se desenvolvendo um pensamento fundado em si mesmo, quando em verdade são totalmente influenciados pelos fatos sociais/econômicos, que ocorrem. Em decorrência disso, esquecem-se dos conflitos humanos que originam o fenômeno jurídico, o que se mostra

\footnotetext{
${ }^{63}$ NUNES, Rizzatto. Manual de introdução ao estudo do direito: com exercícios para sala de aula e lições de casa. 9. ed. São Paulo: Saraiva, 2009, p. 60.

${ }^{64}$ REALE, Miguel. Lições Preliminares de Direito. 25. ed. São Paulo: Saraiva, 2001, p. 60.

${ }^{65}$ AZEVEDO, Plauto Faraco. Ensino Jurídico: o ensino jurídico e a índole da investigação. op. cit., p. 385.

${ }^{66}$ AZEVEDO, Plauto Faraco. op. cit., p. 386.
} 


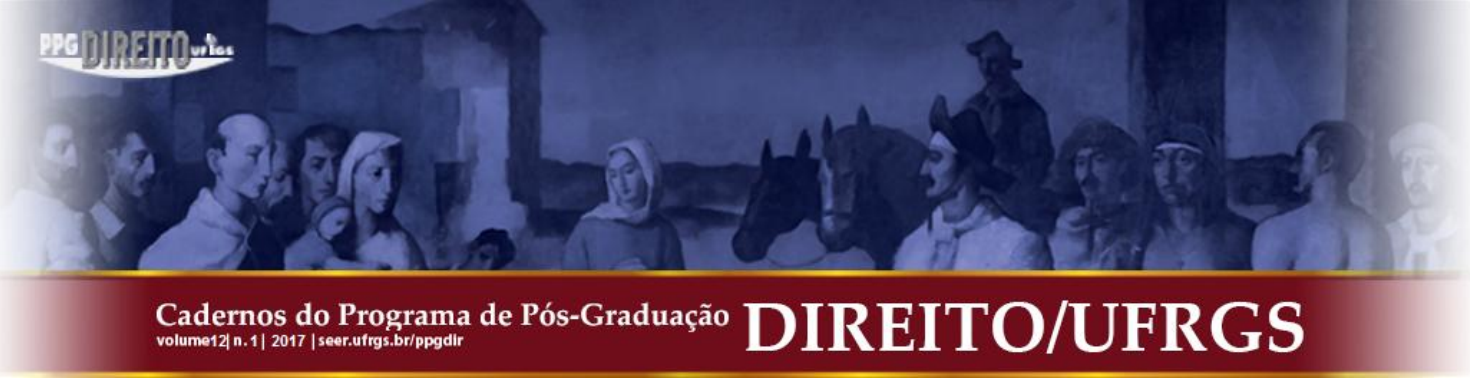

totalmente desarmônico com a ideia de uma investigação jurídica que deve ser voltada para o campo social. ${ }^{67}$

Neste sentido, há que se ter acesso a uma formação intelectual que ultrapasse a fronteira da técnica e valha-se verdadeiramente do conhecimento científico e filosófico para uma melhor compreensão do mundo a sua volta.

Assim, as instituições de ensino contemporâneas devem proporcionar ao estudante de Direito uma formação dogmática, mas também zetética visto que, diante da complexidade das demandas jurídicas existentes e para que seja possível abordar e enquadrar um fato social a este sistema é imperativo compreendê-lo a partir de seus aspectos antropológicos, econômicos, sociológicos, políticos, filosóficos, éticos, históricos sem os quais o sistema ficará afastado de um de seus pilares essenciais, qual seja, o valor.

\section{A BUSCA PELO BEM COMUM COMO UM DOS PRESSUSPOSTOS À CONSOLIDAÇÃO DO ESTADO DEMOCRÁTICO DE DIREITO}

Considerando o conceito de Estado trazido por Dallari, que aborda-o como "uma ordem jurídica soberana que tem por fim o bem comum de um povo situado em um determinado território", é possível identificar que em sua noção há a importante característica de se buscar o bem comum do povo. ${ }^{68}$

Esta característica, tida como o objetivo almejado pela sociedade, esteve presente desde os tempos remotos na história da humanidade e pode ser entendida, segundo Cathrein, como "o complexo das condições requeridas para que todos os homens, individualmente ou em grupos sociais, possam, na medida do possível, atingir livremente e pela própria atividade a sua felicidade terrena". 69

Contemporaneamente, a forma de governo que mais tende a se aproximar desta busca pelo bem comum é a democracia. Isto porque, a democracia além de ser uma ordem constitucional que se fundamenta sob a garantia dos direitos fundamentais, "é um sistema de organização política em que a direção geral dos interesses coletivos compete à maioria do

\footnotetext{
${ }^{67}$ AZEVEDO, Plauto Faraco. op. cit., p. 386.

${ }^{68}$ DALLARI, Dalmo de Abreu. Elementos da teoria geral do Estado. 29. Ed. São Paulo: Saraiva, 2010, p. 119.

${ }^{69}$ CATHREIN, Victor. apud MALUF, Sahid. Teoria Geral do Estado. 30. ed. São Paulo: Saraiva, 2011, p. 337. 
povo, segundo convenções e normas jurídicas que assegurem a participação efetiva dos cidadãos na formação do governo". ${ }^{70}$

No entanto, para que esta definição seja consolidada, vários aspectos devem ser considerados dentro da sociedade, como a possibilidade de que um número considerado de cidadãos possa participar das tomadas de decisões, além de que, os responsáveis pela representatividade dos demais, tenham garantidos a liberdade de opinião, de reunião, de expressão, entre outros direitos. ${ }^{71}$

Baseando-se na premissa de que somente a partir de um estado liberal a democracia poderia ocorrer, necessário se faz mencionar que, em que pese a noção de bem comum contida nesta forma de governo, durante o desenvolvimento das sociedades, o conceito da democracia foi se distanciando daquele disposto anteriormente.

Nos dizeres de Bobbio, pode-se citar seis aspectos das promessas feitas pela democracia que não foram cumpridas: a) o nascimento de uma sociedade pluralista; b) a representação dos interesses sobrepujando a representação política; c) a persistência das oligarquias; d) a limitação do exercício do poder democrático; e) a não eliminação do poder invisível e; f) a ausência da educação para a cidadania. ${ }^{72}$

A contradição da noção moderna sobre o conceito de democracia, apresentada sob estes aspectos, demonstra que o estado atual está ausente de um dos elementos principais à sua formação, qual seja, a sua finalidade, tida como o bem comum. Está-se diante, portanto, de Estados que legalmente se dizem democráticos, mas que na realidade, estão distantes de uma real democracia.

Assim como trazido anteriormente, o fenômeno jurídico é consequência dos fatos ocorridos em comunidade e da forma como estes são valorados, nos termos da teoria de Reale. Sendo assim, conforme destaca Almeida, não valorando os fatos de uma forma adequada, o ordenamento jurídico também será afetado:

Os valores habitam o mundo da cultura e esse é o mundo no qual o homem e a mulher estão inseridos. Consequentemente, o ato de escolha do valor mais elevado, motivador da ação e da consumação da liberdade, é diretamente influenciado pela cultura que o circunda. ${ }^{73}$

\footnotetext{
${ }^{70}$ MALUF, Sahid. Teoria Geral do Estado. 30. Ed. São Paulo: Saraiva, 2011, p. 299.

${ }^{71}$ BOBBIO, Norberto. O futuro da democracia. 6. ed., rev. e ampl. Rio de Janeiro: Paz e Terra, 1997, p. 20.

${ }^{72}$ BOBBIO, Norberto. op. cit., p. 22-33.

${ }^{73}$ ALMEIDA, Guilherme Assis de. Ética e direito: uma perspectiva integrada. São Paulo: Atlas, 2002, p. 43. Cadernos do Programa de Pós-Graduação em Direito PPGDir.JUFRgS | Edição Digital | Porto Alegre | Volume XII | Número 1 | 2017 | P.136 - 165
} 


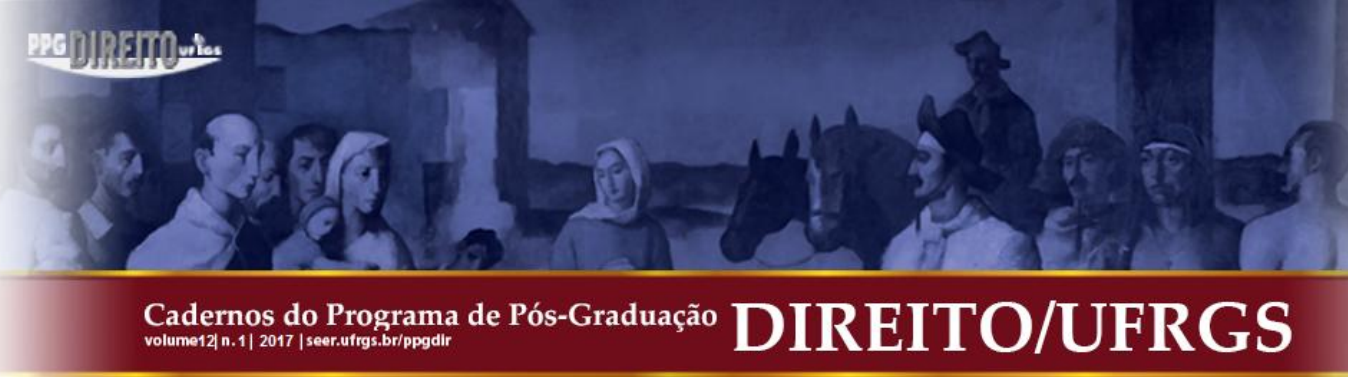

A divergência que ocorre entre o disposto na teoria e o ocorrido na prática, portanto, leva indubitavelmente a criação de normas que independem ou possuem o conteúdo axiológico corrompido. Exemplos claros se dão, quando se analisa o universo de regramentos impondo a realização de condutas esdrúxulas ou dispondo sobre detalhes da convivência em sociedade, que se mostrariam totalmente desnecessários em um estado democrático de direito pleno.

Isso se dá, no entanto, porque o direito pressuposto, tido como o produto históricocultural que condiciona a formulação do direito posto, não é explorado da maneira correta, no sentido da existência de leis que são retrato daquilo que é verdadeiramente necessário para a evolução da sociedade.

Para que o direito possa ser efetivado na realidade e consequentemente o bem comum seja alcançado, consoante afirma Grau, ele deve ser tido como algo que vai além de uma ciência normativa e se encontra como uma "instância da realidade":

[...] a doutrina real do direito não designa, para mim, senão isso, um modo de pensar o direito - , o que me parece suficiente a justificá-lo, dizia, é o fato de que a sua compreensão plena (do direito) transcende a análise exclusivamente da norma. Não se trata apenas de afirmar que o direito é norma, decisão e ordenamento e estrutura, mas, sobretudo — repito — , que o direito é instância da realidade. E que o direito é apreendido do exterior: é uma criação do homem, não redutível às categorias e modelos rígidos da lógica formal. (..) após observar que o direito é produzido a partir de múltiplas inter-relações, compreendi a necessidade de o pensarmos dialeticamente, estudando-o em movimento, em constante modificação, formação e destruição - isto é, como de fato ocorre na realidade concreta. ${ }^{74}$

Diante de uma democracia que se mostra patológica, a reconstrução e a retomada do que se entende por bem comum/valor social, elemento que fundamenta o estado e, por consequência, o direito, se mostra imprescindível. Todavia, estes ideais somente serão alcançados quando se partir da premissa de que a ética (como ciência que possui seus fundamentos sob o bem comum) precede a ideia de Estado e Direito.

Nesta esteira, preceitua Nalini que o universo que fundamenta e está relacionado a todos os outros conhecimentos, corresponde à ética, que engloba e abrange o direito. A ética, assim, condiciona à formulação do direito posto. Desta forma, para que o Estado Democrático de Direito pleno seja alcançado, há a necessidade de que as normas sejam baseadas em preceitos éticos:

\footnotetext{
${ }^{74}$ GRAU, Eros Roberto. Direito posto e direito pressuposto. 7. ed. rev. e ampl. São Paulo: Malheiros, 2008, p.
} 36-44.

Cadernos do Programa de Pós-Graduação em Direito PPGDir./UFRGS | Edição Digital | Porto Alegre | Volume XII | Número 1 | 2017 | P.136 - 165 


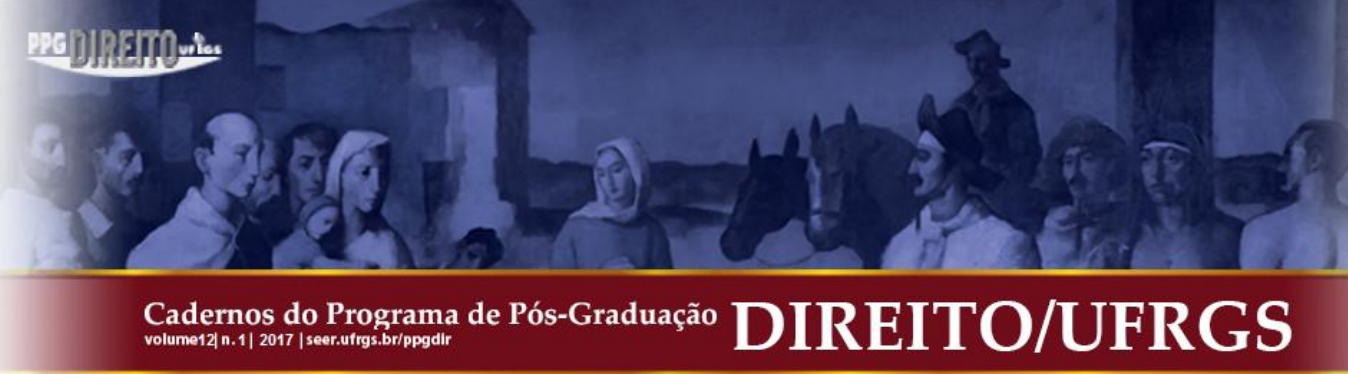

\begin{abstract}
A melhor compreensão, em termos éticos, é pregar e reconhecer que não há direito aético ou antiético. Todas as regras jurídicas, explícitas ou implícitas e em todas as suas categorias, devem um tributo à moral. Seria um contra-senso e uma deterioração dos costumes admitir-se normatividade contrária à ética. Além da legalidade, reclama-se legitimidade ao sistema. E legitimidade é ideia bastante vinculada à fisionomia ética do ordenamento. ${ }^{75}$
\end{abstract}

A ideia de que o Estado, assim como o Direito está contido no campo da ética, se mostram um dos pressupostos para a consolidação do Estado Democrático de Direito. Neste sentido, as discussões do mundo jurídico devem se fundamentar sob aspectos sociológicos e filosóficos, de modo que os estudantes "pensem" o fenômeno cultural e não simplesmente aceitem a vontade de minorias dominadoras que impõe o seu modo de - muitas vezes apenas garantir o poder, sem a preocupação real com a vida da sociedade.

Para que isso seja possível, é importante que se tenha ainda, uma busca diuturna e um aprofundamento no conhecimento do "acervo da humanidade", entendido como o repositório de todos os fatos históricos, culturas, conhecimentos, teorias que a humanidade adquiriu ao longo do tempo:

\begin{abstract}
A humanidade possui um acervo que merece ser protegido e cultivado. Chama-se de acervo ético da humanidade o conjunto de todas as ações, tendências, ideologias, posturas, decisões, experiências compartilhadas, normas internacionais, conquistas políticas, lições éticas, preceitos morais, máximas religiosas, ditos célebres, hábitos populares, sabedorias consagradas que, por seu valor e sua singularidade, servem de referência e espelho para as demais gerações. Patrimônio imaterial de inestimável valor, trata-se de uma somatória histórica de louváveis aspectos do comportamento humano que são capazes de dignificar a pessoa humana, oriundos de todas as civilizações e de todas as culturas. ${ }^{76}$
\end{abstract}

Tendo acesso a este acervo de forma irrestrita, se estará dando ao estudante de Direito condições de interpretá-lo e conhecê-lo, obtendo, assim, os pressupostos necessários para que o direito posto se relacione diretamente com o direito pressuposto.

Isto porque, o intelecto é um elemento essencial para que sejam feitas boas escolhas, pois é através dele que serão realizadas ponderações e análises, deliberando corretamente. As reflexões que o indivíduo realiza são diretamente influenciadas pelo conhecimento, e, julgar tendo por base o senso comum, pode se tornar um problema, pois ausente o intelecto,

\footnotetext{
${ }^{75}$ NALINI, José Renato. Ética geral e profissional. 7. ed. rev., atual. e ampl. São Paulo: Revista dos Tribunais, 2009, p. 124-125.

${ }^{76}$ BITTAR, Eduardo C. B. Curso de ética jurídica: ética geral e profissional. 3. ed., rev. São Paulo: Saraiva, 2005, p. 78-89.
} 


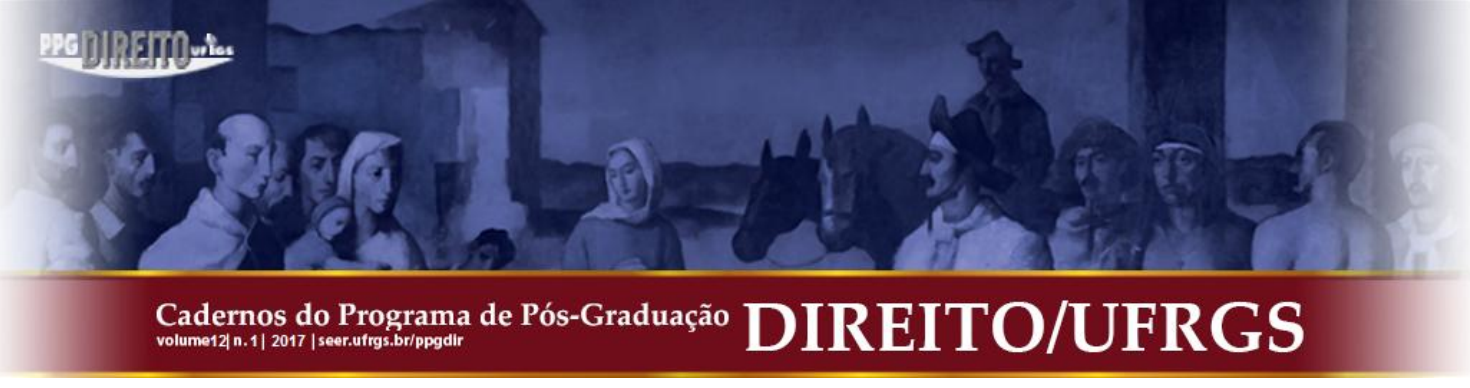

facilmente se julgará errado, considerando fatos e atos de forma viciada, o que comprometerá na maneira como se percebe a ética e se age na sociedade. ${ }^{77}$

Vê-se, assim, a importância de uma boa competência técnica no âmbito do Direito, no entanto, utilizando-se somente dela, os valores ficarão neutros, o que ensejará em julgamentos que submetem somente aos desígnios da lei. ${ }^{78}$

Sob este aspecto há, portanto, uma necessidade de que o "acervo" seja buscado de forma ininterrupta, para que a excelência seja alcançada:

\begin{abstract}
Não se pode deixar de ressaltar ainda que quanto mais se visitar este acervo, quanto mais compreendê-lo, maiores serão as possibilidades para que a excelência venha a acontecer. Não se poderia afirmar que todas as demandas da vida seriam resolvidas com este encadeamento de ações, mas notadamente, quanto mais visitas forem feitas ao acervo, tendo em vista os demais precedentes a este encontro, maior facilidade se terá para responder às crescentes demandas advindas de um ambiente social cada vez mais complexo. ${ }^{79}$
\end{abstract}

O profissional deve estar sempre imerso no universo cultural onde se desenvolve o fenômeno jurídico por ele estudado. Imerso no sentido de ter a visão do todo, buscar e entender as origens do problema e não uma visão restrita que busca a solução imediata, sem se preocupar com as circunstâncias que lhe deram causa.

Neste sentido a busca por um conhecimento integrado, que desenvolva as variadas competências do indivíduo, faz com que os diferentes conflitos ocorridos na sociedade não sejam analisados somente sob um aspecto tecnicista, mas sim, a partir de um senso crítico que tem por fim o bem comum da sociedade.

\title{
CONSIDERAÇÕES FINAIS
}

Podemos concluir de que são muitos os aspectos que influenciaram e influenciam de modo direto na problemática existente na educação jurídica atual, desde questões realmente de ordem educacional até aquelas de cunho político e ideológico.

\footnotetext{
${ }^{77}$ CHALITA, Gabriel Benedito Issaac. Os dez mandamentos da ética. Rio de Janeiro: Nova Fronteira, 2009, p. 100 et. seq.

${ }^{78}$ CHALITA, Gabriel Benedito Issaac. op. cit., p. 6.

79 RAMIRO, Marcus Geandré Nakano. O dever-ser decorrente do medo da sanção: um diálogo entre a efetividade do direito, a formação da consciência moral e as cantigas infantis brasileiras. 2016. 95 f. (Doutorado em Direito) - Pontifícia Universidade Católica de São Paulo, 2016. p. 32. Disponível em <https://sapientia.pucsp.br/bitstream/handle/18865/2/Marcus\%20Geandr\%C3\%A9\%20Nakano\%20Ramiro.pdf> Acesso em 01 março 2017.
} 


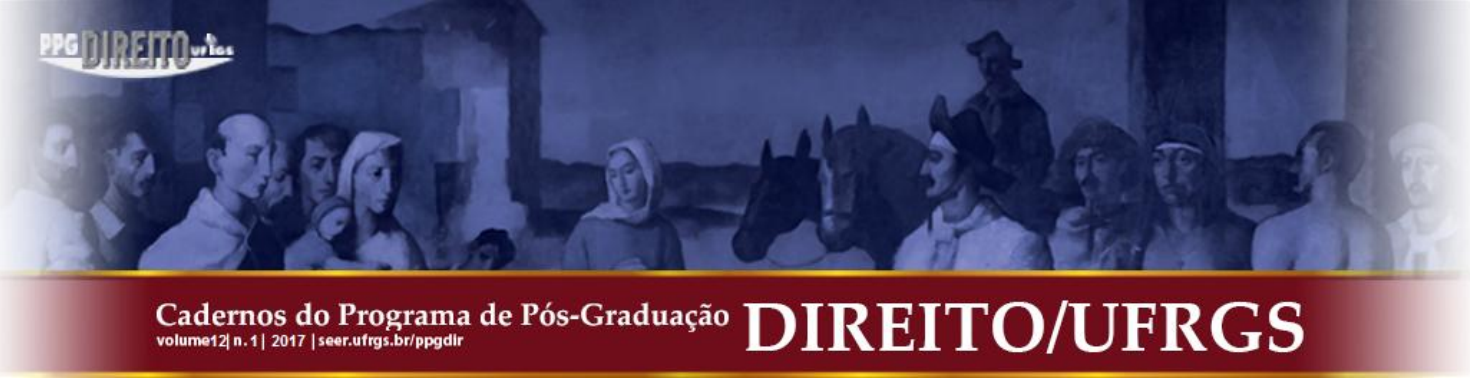

Fica claro que as características atuais dos cursos de Direito do país são em grande parte consequência de uma trajetória focada mais diretamente no suprimento das necessidades burocráticas imediatas do Estado, fazendo com que, desde a criação dos cursos jurídicos até pouco tempo atrás (e em alguns casos, até hoje), o desenvolvimento do senso crítico não seja tido como algo relevante.

Essa preocupação com o desenvolvimento dos conhecimentos humanísticos só ficou mais evidente no país a partir da Lei das Diretrizes e Bases da Educação Nacional (promulgada em 1961) e da Portaria n. 1.886 de dezembro de 1994, onde finalmente se preconizou uma perspectiva mais humanista ao curso de Direito, estabelecendo como disciplinas fundamentais aquelas que possuíam um cunho zetético, como Filosofia Geral e Jurídica, Ética Geral e Profissional, Sociologia Geral e Jurídica, Economia e Ciência Política.

Ocorre que, a inserção destas disciplinas na realidade do estudante de Direito ainda permanece muito superficial visto que, além de existirem muitas dificuldades no sentido de se compreender a importância de uma análise filosófica ou sociológica do fenômeno jurídico, seus temas geralmente não são tratados de forma isolada, fazendo com que ainda se tenha o Direito onde a o caráter técnico predomina sobre o científico.

Não bastasse todos esses problemas, a sociedade contemporânea trouxe ainda a fragmentação de todos os ideais até então como inalteráveis, tornando as relações humanas mais frágeis, egoístas, temporárias e abstratas, o que levou à existência de uma Ciência do Direito ainda mais carente de uma visão global e humana, com demandas jurídicas intrincadas e insolúveis, consoante se observa dos embates hodiernos, travados no Poder Judiciário, mormente, na Corte Suprema.

Neste sentido, percebe-se que os pressupostos para a consolidação do Estado Democrático de Direito, sob esta perspectiva tão necessária, parecem estar em segundo plano e, de consequência, os estudantes se deparam muitas vezes com barreiras que aparentam ser intransponíveis ante os conhecimentos limitados que possuem, tendo em vista que a valoração, como um dos elementos imprescindíveis para a vinculação das demandas do dia-adia à norma, se mostra frágil, despreparada e não prioritária.

Faz-se então necessária, a compreensão crítica dos fatos, a proposta de novas soluções, o protagonismo do profissional do Direito em sua indispensabilidade à administração da justiça, como desejou o legislador constitucional, de modo que aquele que opta por estudar 


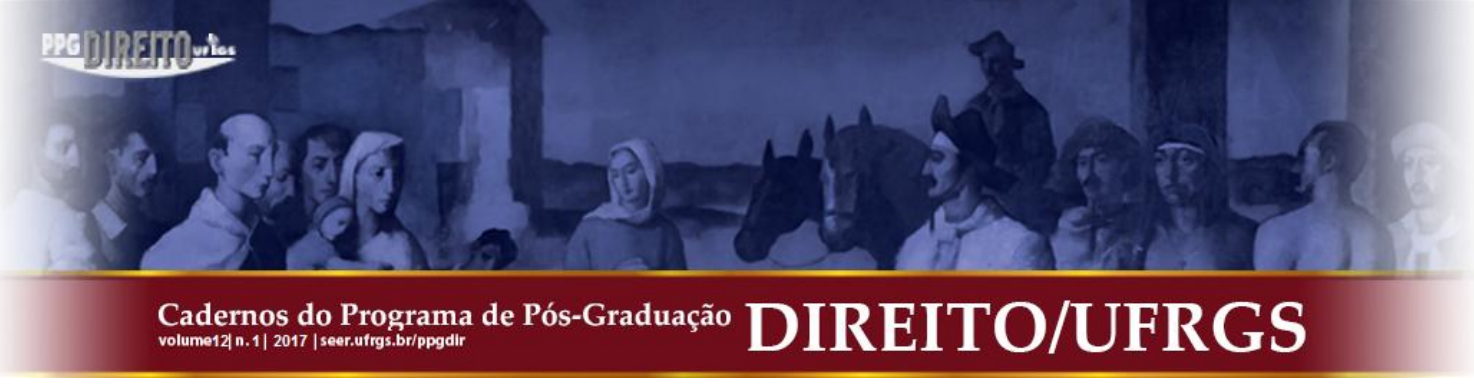

esta ciência, por se enveredar por essas sendas, deve assumir o papel de um agente propulsor da consolidação do Estado Democrático do Direito.

E neste itinerário, dar ao estudante a possibilidade de conhecer irrestritamente o acervo da humanidade apresenta-se como elemento fundamental, sendo a existência de disciplinas zetéticas nos cursos jurídicos um dos pressupostos para que isso aconteça, quando por meio delas o estudante terá acesso a este acervo e poderá compreender que o Direito é uma ciência imersa em um mundo cultural que vai além, portanto, de um mero estudo técnico de normas.

\section{REFERÊNCIAS}

AGUIAR, Roberto Alberto Ramos de. A Crise da Advocacia no Brasil. Anais da Conferência Nacional da Oab, 13, Belo Horizonte. Brasília: OAB, 1990.

ALMEIDA, Guilherme Assis de. Ética e direito: uma perspectiva integrada. São Paulo: Atlas, 2002.

ARNAUD, André Jean. O direito traído pela filosofia. Porto Alegre: Sergio Antonio Fabris, 1991.

AZEVEDO, Plauto Faraco. Ensino Jurídico: o ensino jurídico e a índole da investigação. Anais da Conferência Nacional da Oab, 13, Belo Horizonte. Brasília: OAB, 1990.

BASTOS, Aurélio Wander. O ensino jurídico no Brasil. Rio de Janeiro: Lumen Juris, 1998.

BAUMAN, Zygmunt. Ética pós-moderna. São Paulo: Paulus, 1997.

BEZERRA, Francisco Otávio de Miranda. Ensino Jurídico numa perspectiva cidadã: interação social e políticas públicas. 2006. 236 f. Dissertação (Mestrado em Políticas Públicas) - Universidade Estadual do Ceará, 2006.

BITTAR, Eduardo C. B. Curso de ética jurídica: ética geral e profissional. 3. ed., rev. São Paulo: Saraiva, 2005.

BOBBIO, Norberto. O futuro da democracia. 6. ed., rev. e ampl. Rio de Janeiro: Paz e Terra, 1997.

BOVE, Luiz Antonio. Uma Visão Histórica do Ensino Jurídico no Brasil. Revista do Curso de Direito, São Paulo, v. 3, n. 3, p. 115-138, 2006. Disponível em: <http://www.bibliotekevirtual.org/revistas/Metodista-SP/RCD/v03n03/v03n03a06.pdf> Acesso em: 20 maio 2016. 


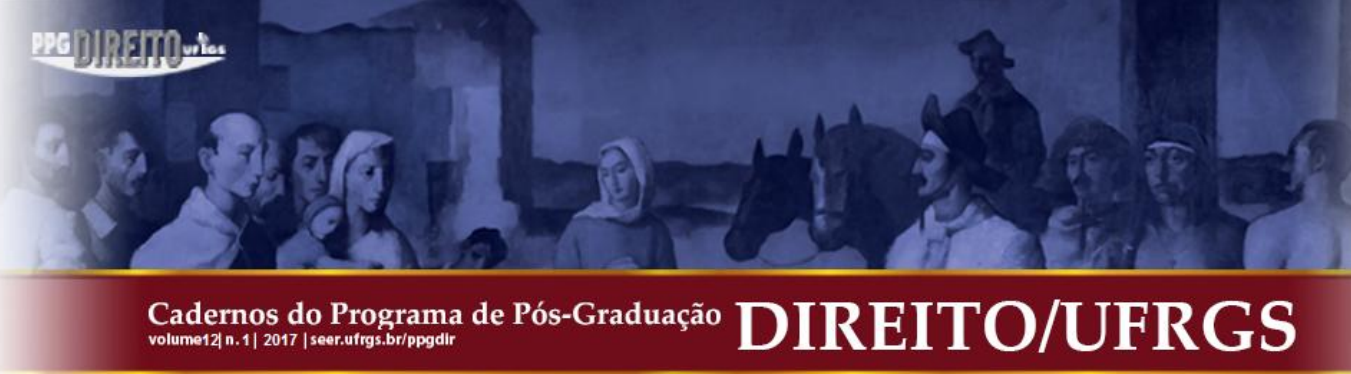

BRASIL. Lei $\mathrm{n}^{\circ}$ 4.215, de 27 de abril de 1963. Brasília, 1963. Disponível em: <http://www.planalto.gov.br/ccivil_03/leis/1950-1969/L4215.htm>. Acesso em: 22 maio 2016 .

Lei $\mathrm{n}^{\circ}$ 5.540, de 28 de novembro de 1968. Brasília, 1968. Disponível em: <http://www.planalto.gov.br/ccivil_03/leis/L5540.htm〉. Acesso em: 22 maio 2016.

. Lei $\mathrm{n}^{\mathrm{o}}$ 8.906, de 4 de julho de 1994. Brasília, 1994. Disponível em:

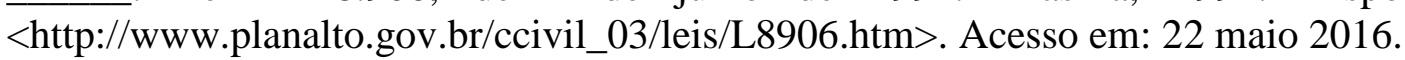

Decreto $\mathrm{n}^{\circ} 1232 \mathrm{H}$, de 2 de janeiro de 1891. Rio de Janeiro, 1891. Disponível em: <http://www.camara.gov.br/Internet/InfDoc/novoconteudo/Legislacao/Republica/LeisOceriza das/1891dgp-jan.pdf>. Acesso em: 22 maio 2016.

. Lei $\mathrm{n}^{\mathrm{o}}$ 4.024, de 20 de dezembro de 1961. Brasília, 1961. Disponível em: <http://www.planalto.gov.br/CCIVIL_03/leis/L4024.htm>. Acesso em: 22 maio 2016.

Portaria Ministerial n 1.886, de 30 de dezembro de 1994. Brasília, 1994. Disponível em: <http://www.migalhas.com.br/arquivo_artigo/art20100108-03.pdf>. Acesso em 03 abr. 2017.

Resolução CNE/CES no 9, de 29 de setembro de 2004. Brasília, 2004. Disponível em: <http://portal.mec.gov.br/cne/arquivos/pdf/rces09_04.pdf >. Acesso em: 22 maio 2016.

CATHREIN, Victor. apud MALUF, Sahid. Teoria Geral do Estado. 30. ed. São Paulo: Saraiva, 2011.

CHALITA, Gabriel Benedito Issaac. Os dez mandamentos da ética. Rio de Janeiro: Nova Fronteira, 2009.

CHAUÍ, Marilena. Público, Privado, Despotismo. In: NOVAES, Adauto (Org.). Ética. São Paulo: Companhia das Letras, 2007.

DALlARI, Dalmo de Abreu. Elementos da teoria geral do Estado. 29. ed. São Paulo: Saraiva, 2010.

DANTAS, Francisco Clementino de San Tiago. A Educação Jurídica e a Crise Brasileira. Rio de Janeiro: Escola de Direito do Rio de Janeiro da Fundação Getúlio Vargas, 2010.

A Educação Jurídica e a Crise Brasileira. Cadernos FGV Direito Rio, Educação e Direito, v.3, 2009.

EXAME de Ordem em números. v. III. Disponível em: < http://fgvprojetos.fgv.br/publicacao/exame-de-ordem-em-numeros-vol3>. Acesso em: 15 ago. 2016. 


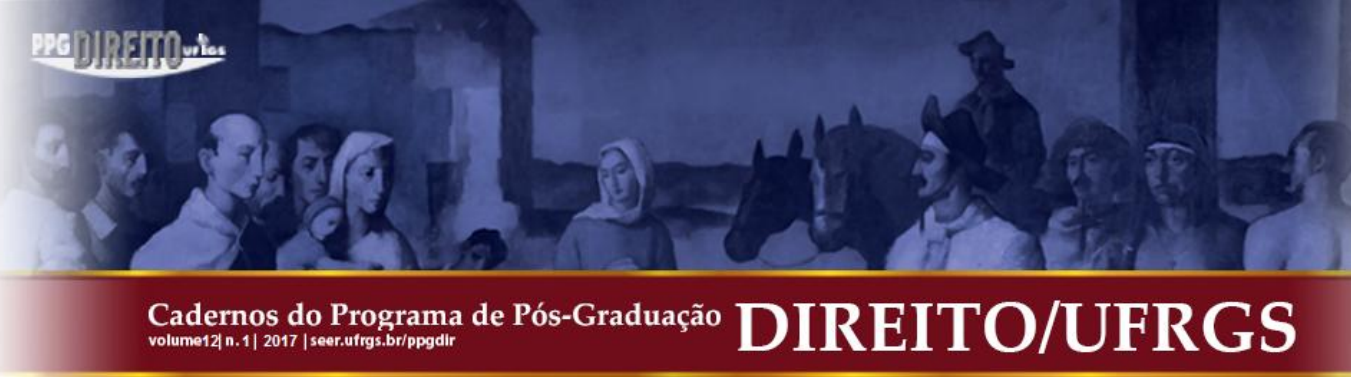

FERRAZ JÚNIOR, Tércio Sampaio. Introdução ao estudo do direito: técnica, decisão, dominação. 6. ed. São Paulo: Atlas, 2008.

FUSTEL DE COULANGES. A cidade antiga: estudo sobre o culto, o direito as instituições da Grécia e da Roma. Tradução de Jonas Camargo Leite e Eduardo Fonseca. São Paulo: Hemus, 1975.

GRAU, Eros Roberto. Direito posto e direito pressuposto. 7. ed. rev. e ampl. São Paulo: Malheiros, 2008.

INSTITUIÇÕES de Educação Superior e Cursos Cadastrados. Disponível em: <http://emec.mec.gov.br/>. Acesso em: 24 maio 2016.

LÔBO, Paulo Luiz Neto. Ensino jurídico: ensino jurídico na atualidade brasileira. Anais da Conferência Nacional da Oab, 13, Belo Horizonte. Brasília: OAB, 1990.

LOPES, José Reinaldo de Lima. O direito na história: lições introdutórias. São Paulo: Max Limonad, 2011.

MACHADO, Antônio Alberto. Ensino Jurídico e Mudança social. 2. ed. São Paulo: Atlas, 2009.

MALUF, Sahid. Teoria Geral do Estado. 30. ed. São Paulo: Saraiva, 2011.

MATA-MACHADO, Edgar de Godoi da. Elementos de teoria geral do direito: para os cursos de introdução à ciência do direito. Belo Horizonte: Vega, 1972.

MONTORO, André Franco. Introdução à ciência do direito. 5. ed. São Paulo: Martins, 1974.

NALINI, José Renato. Ética geral e profissional. 7. ed. rev., atual. e ampl. São Paulo: Revista dos Tribunais, 2009.

NASCIMENTO, Walter Vieira do. Lições de história do direito. 15. ed., rev. e aum. Rio de Janeiro: Forense, 2004.

NUNES, Rizzatto. Manual de introdução ao estudo do direito: com exercícios para sala de aula e lições de casa. 9. ed. São Paulo: Saraiva, 2009.

OAB. Conselho Federal. Ensino jurídico - OAB. Balanço de uma experiência. Brasília: OAB, 2000.

RAMIRO, Marcus Geandré Nakano. O dever-ser decorrente do medo da sanção: um diálogo entre a efetividade do direito, a formação da consciência moral e as cantigas infantis brasileiras. 2016. 95 f. (Doutorado em Direito) - Pontifícia Universidade Católica de São Paulo, $2016 . \quad$ Disponível em <https://sapientia.pucsp.br/bitstream/handle/18865/2/Marcus\%20Geandr\%C3\%A9\%20Nakan o\%20Ramiro.pdf> Acesso em 01.03.2017. 


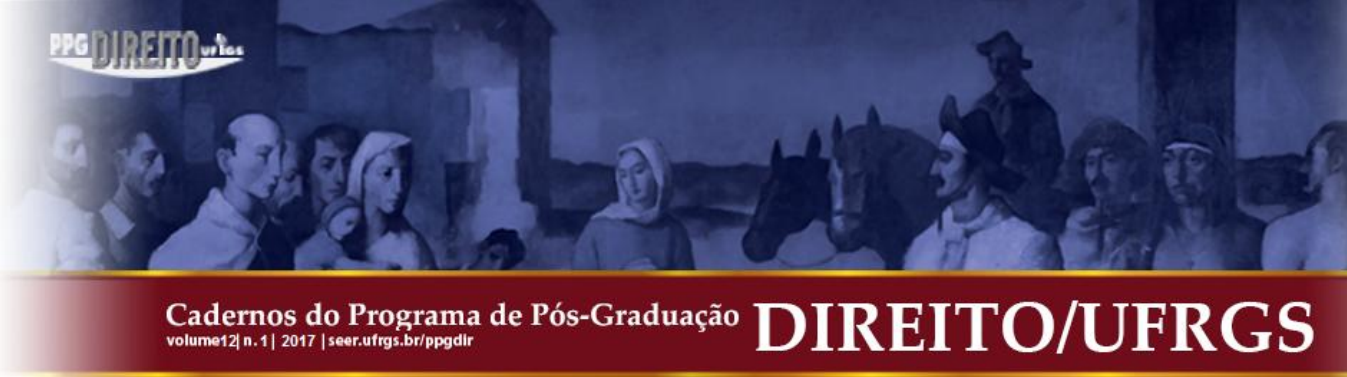

REALE JÚNIOR, Miguel. Criação e Degenerescência do Ensino Jurídico. Revista USP, São Paulo, n. 100, p. 87-96, 2013-2014. Disponível em: < http://www.revistas.usp.br/revusp/article/view/76171>. Acesso em: 20 maio 2016.

REALE, Miguel. Lições Preliminares de Direito. 25. ed. São Paulo: Saraiva, 2001.

SAMPAIO, Helena. O ensino superior no Brasil: o setor privado. São Paulo: Hucitec, 2000.

SANT'ANNA, Sérgio Luiz Pinheiro. Crítica e reflexão sobre o ensino jurídico no Brasil considerações acerca do papel do advogado nas transformações sociais dentro de uma visão histórica e política. Anais da Conferência Nacional da Oab, 13, Belo Horizonte. Brasília: OAB, 1990.

VENÂNCIO FILHO, Alberto. Das Arcadas ao Bacharelismo. 2. ed. São Paulo: Perspectiva, 1982.

WOLKMER, Antônio Carlos. Fundamentos de história do direito. 8. ed., rev. e ampl. Belo Horizonte: Del Rey, 2014.

XAVIER, Maria Elizabete S. P.; RIBEIRO, Maria Luísa Santos; NORONHA, Olinda Maria. História da educação: a escola no Brasil. São Paulo: FTD, 1994. 


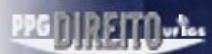

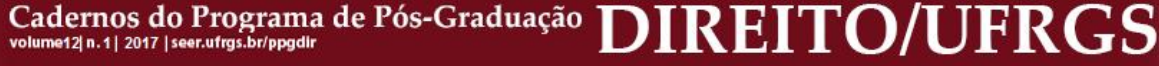

165 